\title{
Quantifying anthropogenic modification of the shallow geosphere in central London, UK
}

\author{
R.L. Terrington ${ }^{\text {a,* }}$, E.C.N. Silva ${ }^{\text {b }}$, C.N. Waters ${ }^{\text {a,c }}$, H. Smith ${ }^{\text {a }}$, S. Thorpe ${ }^{a}$ \\ a British Geological Survey, Environmental Science Centre, Keyworth, Nottinghamshire NG12 5GG, UK \\ b São Paulo State University (UNESP), Faculty of Science and Technology (FCT), Presidente Prudente, São Paulo, Brazil \\ c School of Geography, Geology and the Environment, University of Leicester, Leicester LE1 7RH, UK
}

\section{A R T I C L E I N F O}

Article history:

Received 23 March 2018

Received in revised form 5 July 2018

Accepted 5 July 2018

Available online 6 July 2018

\section{Keywords:}

Anthropocene

Artificial ground

City of London

Tower Hamlets

\begin{abstract}
A B S T R A C T
The veneer of artificial (anthropogenic) deposits present beneath contemporary cities is commonly markedly heterogeneous, particularly in cities such as London with a history of two millennia of development. To what extent can the analysis of borehole data, historical land use maps and digital terrain models provide adequate assessment of such heterogeneity? Two adjacent London boroughs, City of London and Tower Hamlets, are selected because of their contrasting historical development and current land use. Statistical comparison of the variations in deposit thickness is related to the natural Holocene topography, underlying geological deposits (non-anthropogenic deposits) and heights of overlying buildings. Estimates of the volume $\left(\sim 67 \mathrm{million}^{3}\right)$ and mass ( $\sim 100$ million tonnes) of the deposits and additional volume ( 359 million $\left.\mathrm{m}^{3}\right)$ and mass ( 25 million tonnes) of buildings provides indication of additional loading that may cause local compaction or regional subsidence, a concern during a time of rising global sea level. Extrapolated across Greater London, the mass of anthropogenic deposits is estimated at $~ 6$ billion tonnes. Assessment of the compositional variations within the artificial deposits provides an approximation of accumulation rates post-World War II. A potential event horizon, coincident with the early 1940s Blitz, could not be demonstrated as an extensive marker, but distinct lithological compositions for post-World War II strata are broadly coincident with the globally resolved signals marking the start of the Anthropocene Epoch.
\end{abstract}

(c) 2018 Elsevier B.V. All rights reserved.

\section{Introduction}

The intentional movement of earth, associated with house and road construction and mineral production, has been estimated globally to be $<1 \mathrm{Gt} / \mathrm{yr}$ for most of the last $10,000 \mathrm{yr}$ (Hooke, 2000). This time interval, formally known geologically as the Holocene Epoch, has been proposed by some to equate with an early Anthropocene concept (e.g., Smith and Zeder, 2013) that includes the spread of agriculture, the creation of civilizations and the onset of urban habitation. The geological Anthropocene is proposed to commence in the mid-twentieth century, at a time of post-War rapid increase in global population, consumption and trade, with resultant marked environmental signals (Waters et al., 2016; Zalasiewicz et al., 2017b). Significant anthropogenic impact on the geomorphological evolution of landscapes during the Holocene are well documented, such as can be seen in the western Netherlands where the sustained industrial extraction of peat has led to a drop in the ground surface of approximately $10 \mathrm{~m}$ across the entire coastal zone, causing significant flooding of the inhabited landscape (Kluiving and Hamel, 2016). One aspect of interest in this study is the

\footnotetext{
* Corresponding author.

E-mail address: rte@bgs.ac.uk (R.L. Terrington).
}

assessment of the extent that the development of the urban environment in London, evidenced in the artificial deposits accumulating beneath the built environment, represents either a gradual evolution with time or displays a step-change in development coincident with the geological Anthropocene concept.

Anthropogenic influence on the evolution of the urban landscape, particularly of the shallow geosphere that makes up the foundation of our cities, is well known but poorly quantified geologically. It is better quantified archaeologically, for example when measuring the physical geometry and timing of development of the built environment (Abrams, 1994), but the extents of these areas tend to be limited to site scale examples. The often complex interrelationships between anthropogenic and natural geological strata commonly use excavations to help produce localised 3D models, such as defining the occupation debris and landscapes associated with the former position of the River Amstel in Amsterdam (Kranendonk et al., 2015). In such circumstances, boreholes can provide a valuable tool in assessing the landscape evolution, though typically these are designed arrays in which the cores are inspected as part of the study and radiocarbon dating and artefact types used to determine the relative ages of the succession (e.g., Verhagen et al., 2017; Bini et al., 2018). In the current study, we aim to assess the extent that huge volumes of archival borehole data, 
collected mainly for assessment of engineering ground conditions, can be useful in analysing the evolution of anthropogenic deposits in a complex historical landscape without direct access to the borehole core.

An attempt to quantify the distribution and thickness of artificially modified ground (AMG) in London by Ford et al. (2014) provided a mean thickness of undifferentiated anthropogenic deposits of $1.6 \mathrm{~m}$, with thickest developments in the east of the city, mainly close to the River Thames. However, this study, based on published geological maps, barely registered any such deposits across large parts of Greater London, suggesting a significant under-representation of the deposits. This reflects the approach taken in the production of maps in this area that did not spatially delimit areas of worked and landscaped ground, and to show only the thickest developments of such strata. Consequently, the published 1:50,000-scale geological map (BGS, 2006) and component 1:10,000-scale geological maps that cover the study area do not explicitly show AMG for the main part of Tower Hamlets and the entirety of City of London. The extent of AMG has been deliberately reduced on analogue geological maps as it can obscure complex relationships in underlying natural deposits and it is acknowledged that for older urban areas much of the surface has been partially or wholly disturbed by human activity. Attempts have been made to increase the coverage of AMG in 3D geological models in urban areas as these do not suffer the same limitations in their outputs where the AMG can be hidden to reveal the underlying non-anthropogenic natural deposits (Burke et al., 2014; Thorpe, 2015). However, such models tend to be manually processed, using a limited number of data points and do not take into account the age of AMG. Is there a process by which more precise AMG thicknesses can be estimated and is it feasible to determine when these deposits accumulated?

Two boroughs, the City of London and Tower Hamlets (Fig. 1), are studied to provide estimates of the scale of anthropogenic sediment flux in a representative part of central London. This study includes and builds upon work carried out in the City of London by Silva (2016) that includes a brief account of the contrasting histories of development in the two areas. The City of London $\left(3.15 \mathrm{~km}^{2}\right.$ in area) was initially developed during Roman times and is currently a business area that has had little history of industrial development. This contrasts with Tower Hamlets (21.57 $\mathrm{km}^{2}$ in area), which mainly expanded during the nineteenth century, saw significant industrial development associated with the Docklands and has been reinvented as a financial centre in the late twentieth century.

The two key objectives of this paper are:

1. To describe the techniques used to identify and quantify historical and modern land use, and give an assessment of land-use evolution in this part of London.

2. To quantify thickness, volume, mass and accretion of the total AMG in context with land-use type and evolution.

This paper explores the potential causes of variations of AMG thickness, including natural topographic features such as rivers and the underlying non-anthropogenic geology. The data and methods used to do this are described in the following section.

\section{Data synthesis}

The study uses remote techniques including appraisal of historical and modern maps, borehole records, and a modern digital terrain model (DTM) to obtain land level elevation values to assess the temporal evolution of the city landscape and relate this to dynamic urban land-use domains. The techniques and data mentioned in this study allow the combined volume and mass of AMG, both above and below modern land surface, to be estimated and analysed against different factors that may have influenced this by comparing against both recent and historical land-use records. These results can be extrapolated to other urban areas with similar modern and historical land use with either a long-history of urban development (>1000 yr; e.g., City of London) and areas with a shorter urban history ( $>100 \mathrm{yr}$; e.g., Tower Hamlets).

The key datasets used to measure the total abundance of AMG and help define both modern and historical land use are detailed as follows.

\subsection{European urban atlas}

The European Urban Atlas (Urban Atlas), part of the local component of the GMES/Copernicus land monitoring services, is the baseline dataset used in this study to define current land use. It provides reliable, inter-comparable, high-resolution land use maps for 305 Large Urban Zones and their surroundings ( $>100,000$ inhabitants as defined by the Urban Audit) for the reference year 2006. Land use has been divided into several classifications: Urban Fabric (ranging from Continuous $(>80 \%)$ to Discontinuous $(<10 \%)$ ); Industrial; Commercial; Public (such as parks); Military; Private; and Transport Units.

Linear features, such as roads, railways and water courses (docks, canals and rivers) are removed to ensure that when averaging out the maximum thickness of AMG against land use, the large area that these features occupy are not influenced by localised thickness variations.

\subsection{Historical and modern maps}

Historical land use is interpreted using contemporary records, including Greenwood's Map of London Greenwood and Greenwood (1827), Beek's Plan of Sewers (1843), Ordnance Survey (OS) historical maps at 1:10,560-scale $(1882,1896,1898)$, and Ward's (2015) bomb damage maps. Modern OS data at 1:1250-, 1:2500- and 1:10,000-scales from 2015 is used in conjunction with the European Urban Atlas. Interpretations of the pre-Victorian former land use rely upon archaeological reconstructions (Brigham, 2000).

\subsection{Digital surface model (DSM)}

A high resolution LiDAR digital surface model (DSM), is used to estimate the height and volume of buildings (i.e., the above surface AMG) and used in conjunction with start heights recorded in borehole records to determine evidence for vertical accretion of artificial deposits or loss through excavation (i.e., the below surface AMG). The DSM is at $1 \mathrm{~m}$ resolution and was released in 2006 in a joint venture between Bluesky and Infoterra (@Getmapping: Licence Number UKP2006/01). The average height of the buildings/land cover was calculated per European Urban Atlas land use area using this data.

\subsection{Boreholes (BGS borehole geology database)}

The BGS has a large database of borehole records for the study area (8091; Table 1), many of which have been digitally transcribed or interpreted from the borehole scans that were recorded at the time of the site investigation in a driller's log (Fig. 2).

Of the total number of borehole records held in the BGS database, approximately $49 \%$ of the boreholes in the City of London and $45 \%$ in Tower Hamlets have AMG described (Table 1 and Fig. 3). The AMG thickness recorded in the logs is used in this study to estimate the total thickness, subsurface volume and mass of AMG within the two boroughs. The historical ground elevation can be determined using borehole start heights, i.e. the ground elevation measurement at the time the borehole was drilled. The proportion of boreholes that have a recorded start height (the surface elevation at the time the borehole was drilled) was $71 \%$ for the City of London and 78\% for Tower Hamlets (Table 1).

Descriptions of the material recorded in boreholes are used as a proxy to define areas of historically different land-use types and evolution, and to try and establish a relationship between land-use type and AMG thickness (see Section 4). 

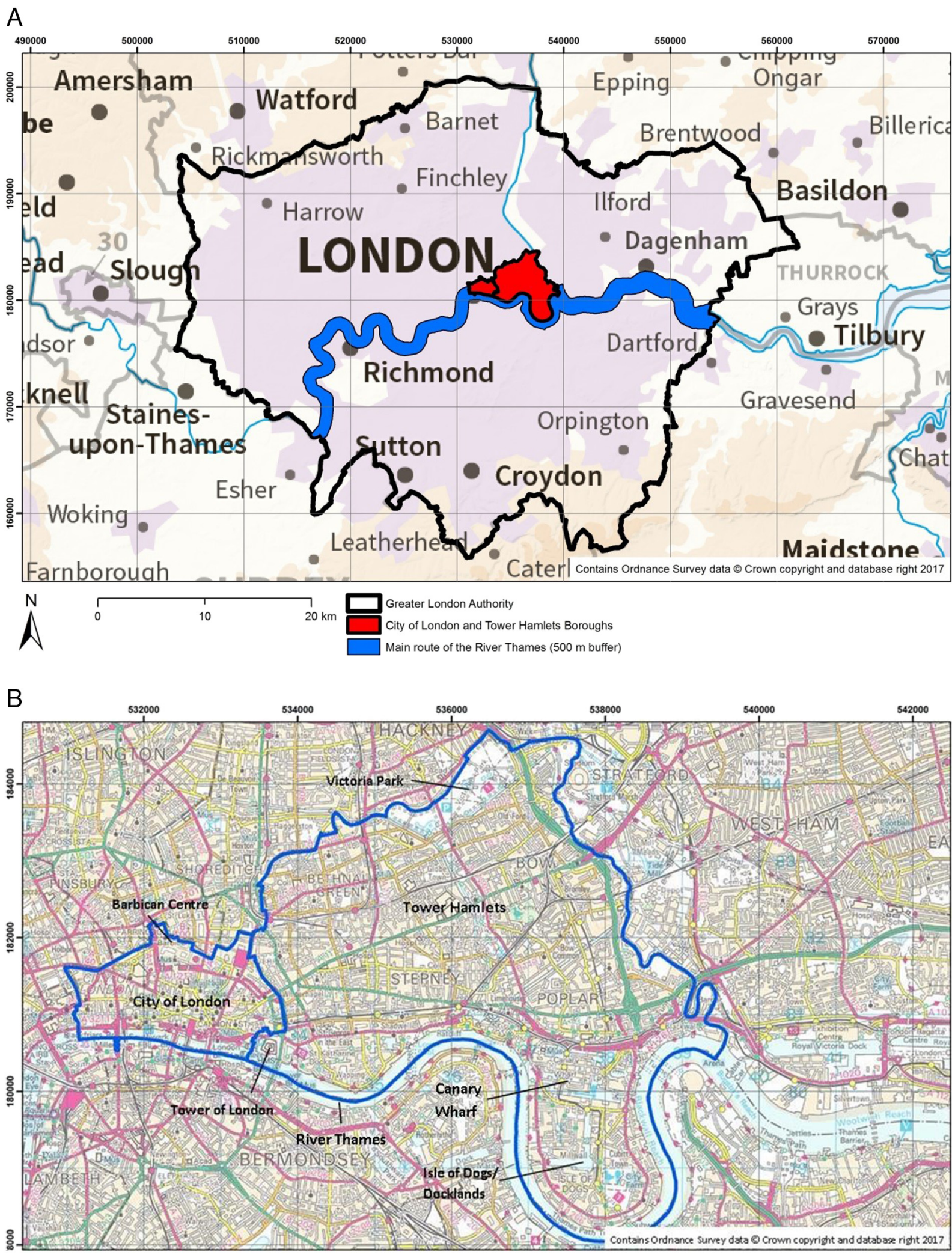

Fig. 1. Study area showing the City of London and Tower Hamlets.

\section{Classification of artificially modified ground}

Anthropogenic deposits are the material accumulations formed by human action, which along with human reshaping of the landscape through excavation and transportation of material forms part of AMG. This study follows Ford et al. (2014) in the use of the morpho-genetic approach to classifying AMG into five mapped categories based upon morphological relationships, categorised into sub-units based upon the relationships to land use (Fig. 3):

- Made Ground: areas where material is known to have been placed by humans onto the pre-existing natural land surface, including 
Table 1

Total number of boreholes with AMG recorded.

\begin{tabular}{llll}
\hline & $\begin{array}{l}\text { Total number of } \\
\text { boreholes in the } \\
\text { BGS database }\end{array}$ & $\begin{array}{l}\text { Number of } \\
\text { boreholes with } \\
\text { start heights }\end{array}$ & $\begin{array}{l}\text { Number of boreholes } \\
\text { with AMG interpreted } \\
\text { into the BGS database }\end{array}$ \\
\hline $\begin{array}{l}\text { City of London } \\
\text { Tower Hamlets }\end{array}$ & 63538 & 1239 & 853 \\
\hline
\end{tabular}

engineered fill such as road, rail and canal embankments and dumps of dredged materials from natural river channels (e.g., Mudchute Park, Isle of Dogs). Made Ground deposits in excess of $1 \mathrm{~m}$ thick, although not shown on published BGS geological maps for the area, are proved by borehole data to be extensive (Fig. 3);

- Worked Ground: areas where the pre-existing land surface is known to have been excavated by humans. In the study area it is dominated by excavations for the Docklands in Tower Hamlets, but also includes cuttings for the metro system and for ornamental lakes in Victoria Park;

- Infilled Ground: areas where the pre-existing land surface has been excavated and subsequently partially or wholly backfilled by humans. In the study area it is dominated by the infill of parts of the Docklands excavations in Tower Hamlets at Wapping, Canary Wharf and Isle of Dogs;

- Disturbed Ground: areas of surface or near-surface mineral workings where ill-defined excavations, areas of subsidence caused by workings, and spoil are complexly related. This is mainly associated with brickearth workings in the study area, but these deposits have been commonly buried by subsequent development and are now shown as Made Ground;

- Landscaped Ground: areas where the pre-existing land surface has been extensively remodelled but where it is impracticable to delineate separate areas of Made Ground, Worked Ground or Disturbed Ground. Landscaped Ground is not explicitly shown on published 1:50,000 scale geological maps of the area, with the exception of small areas of industrial development in Tower Hamlets, but is likely to be more extensive in areas where Made Ground is not observed.

\section{Modern and historical land use and the impact upon the composition of artificially modified ground}

\subsection{Evolution of the urban London landscape from Roman to modern times}

The City of London is the oldest part of metropolitan London, founded around $47 \mathrm{CE}$ as Londinium by the Romans. The construction of the City Wall from early second century defined the shape of the city (Merrifield, 1965; Brigham, 2000; Perring and Brigham, 2000), which was also constrained by the River Thames to the south (Fig. 4a). The Thames, along with the now subterranean tributary Rivers Fleet and Walbrook, served as vital sources of fresh water, acted as a sewage system, and crucially allowed transportation and thus early industry to flourish. The Thames Estuary connection to the North Sea resulted in the development of a significant Roman trading port at the mouth of the Walbrook, which continued to thrive despite being razed to the ground in $60 \mathrm{CE}$. Key archaeological finds relate to the quay and waterfronts, buildings (including the forum, amphitheatre, Temple of Mithras and bath-house) and burial sites, the latter occurring mainly outside the City Wall (Perring and Brigham, 2000). AMG associated with this phase of development was likely to be dominated by natural stone masonry, bricks and tiles.

Roman occupation of the City of London ceased in the fifth century. For the next two centuries the area was predominately populated by Anglo-Saxons and the area went largely undeveloped (Fig. 4a and b).

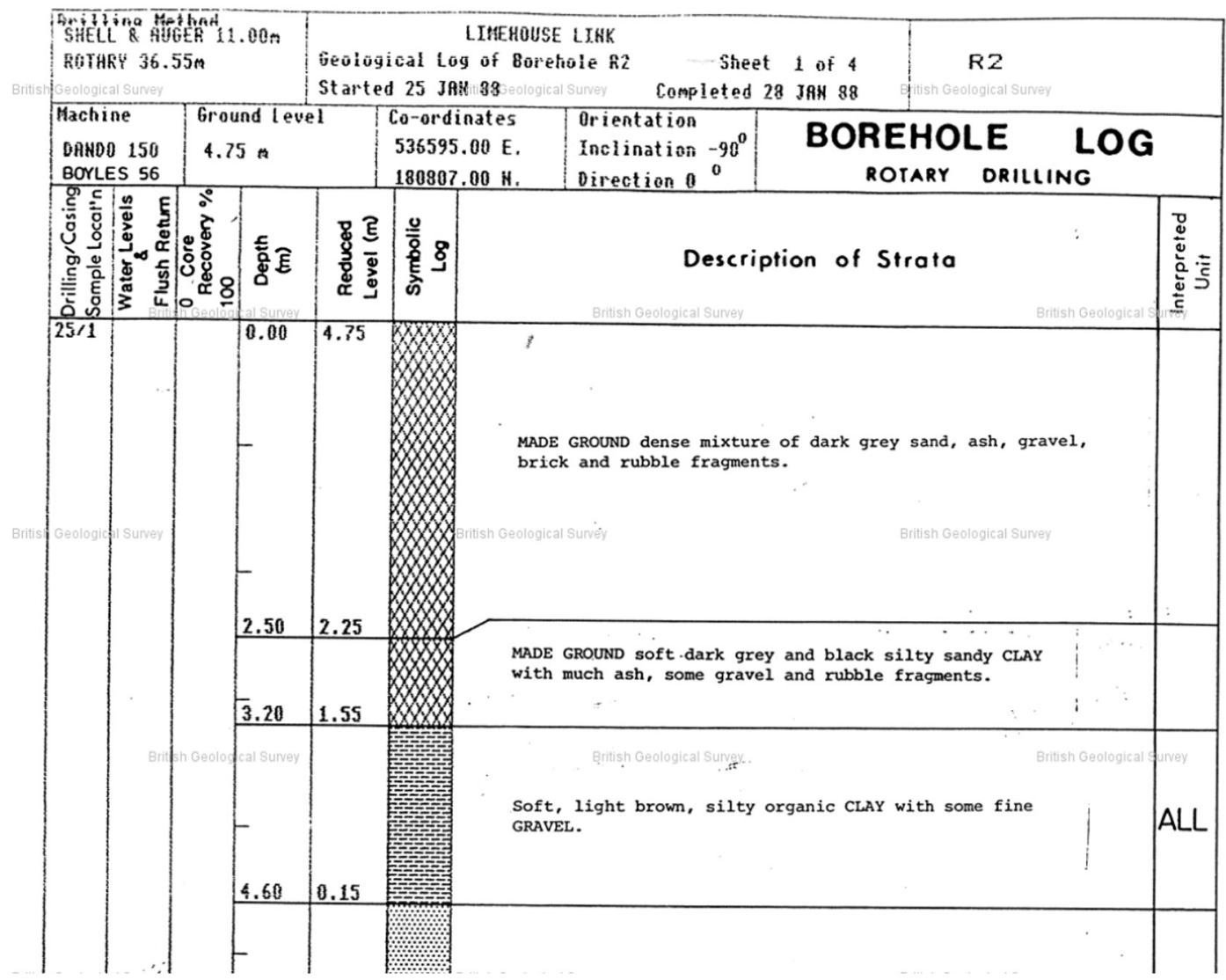

Fig. 2. Borehole scan of driller's log showing index level information and description of AMG. 


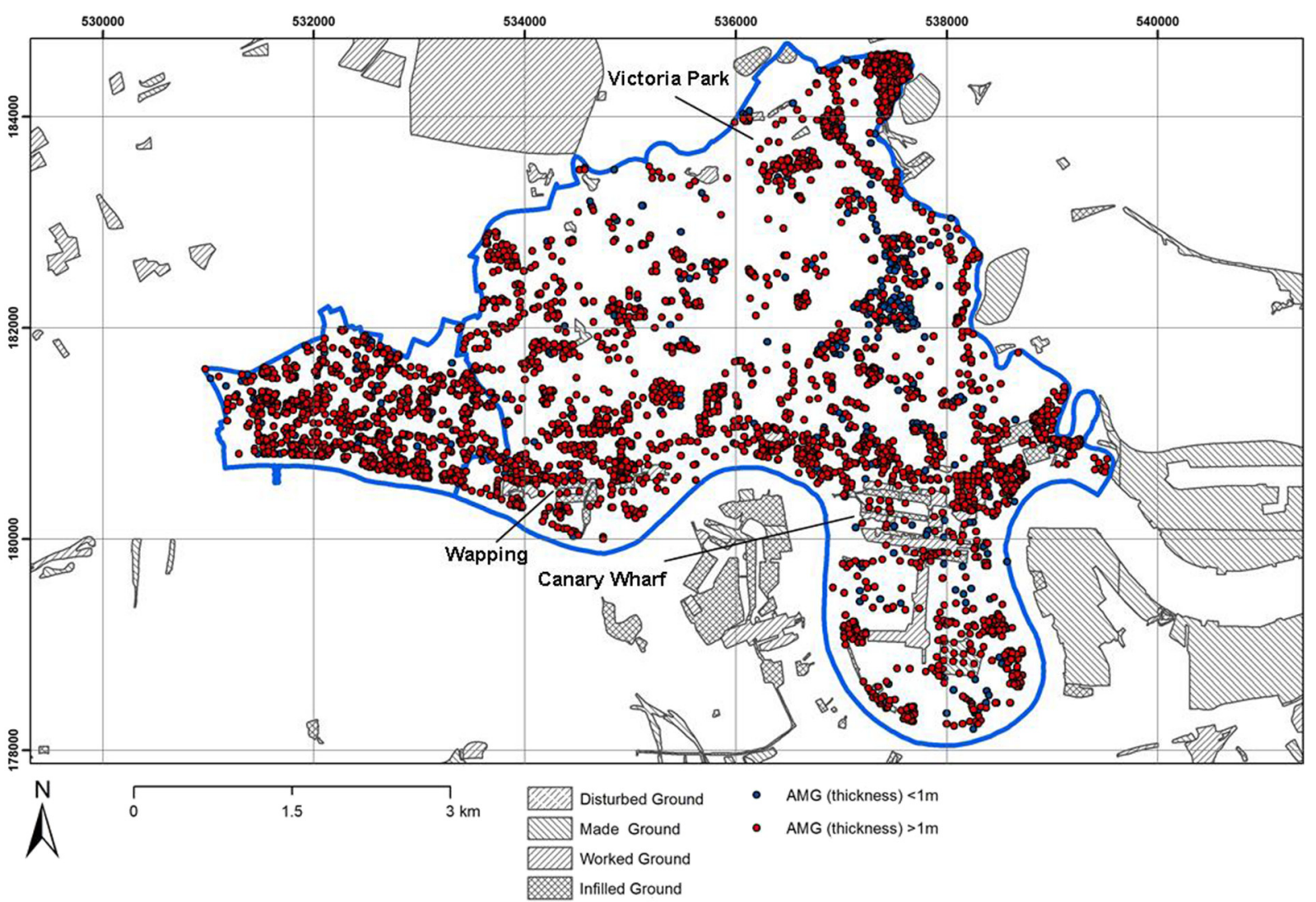

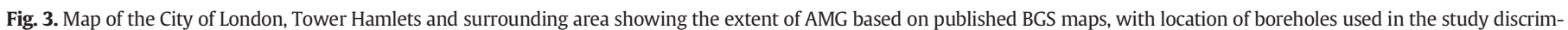
inated between those that prove $>1 \mathrm{~m}$ and $<1 \mathrm{~m}$ thickness of AMG.

Resurgence in Christianity in the seventh century saw the growth of a trading centre along the Strand and the re-emergence of London as a town. It is likely that AMG during this time included reworked building materials from the Roman occupation and it is therefore difficult to differentiate between deposits from these time intervals. The main Anglo-Saxon constructions included huts, churches (including the first St. Paul's Cathedral in 604 CE), pits, sunken buildings, ditches, refuse pits and burial sites (Cowie and Harding, 2000).

The Medieval settlement occurred within the extent of the City Wall, but with expansion to the west at Blackfriars in the thirteenth century (Fig. 4c). Evidence from the medieval period (from 1066 to 1500 CE) includes the remains of houses, churches, bridges, gates, cemeteries, tanneries and castles (Sloane et al., 2000).

Deposits associated with the post-Medieval period ( 1500 to $\sim 1800 \mathrm{CE}$ ) are difficult to detect because of subsequent rebuilding, however, one event that can be distinguished from this period is the Great Fire of London in 1666. Most buildings prior to 1666 were timberframed with comparatively low potential for preservation, whereas it is probable that the dug features of rural settlements that sat outside the medieval city boundary, such as wells and cesspits, will have had a greater chance of preservation (Schofield, 2000). Post-1666, the Rebuilding Acts required that new constructions should be in brick or stone and streets to be paved (Department of Planning and Transportation, 1994), leading to the development of Regency architecture, which is still evident in many parts of the City of London.

During the nineteenth century the city saw a marked increase in population as a result of the Industrial Revolution, and with it new brick-built housing stock particularly in parts of Tower Hamlets not previously developed (Fig. 4d). There were significant improvements and changes in London's roads (notably widening and the introduction of a grid pattern), railways, subways (Williams et al., 2014), sewage systems (Plan of Sewers, 1843), and the construction of
Victoria Embankment in the City of London. During 1855-1939, the City of London was rapidly transformed into an office and commercial centre along with construction of grand public buildings and loss of housing stock. About $80 \%$ of buildings in the City of London were replaced by commercial premises between 1855 and 1905, and about 20\% of buildings replaced between 1905 and 1939 (Department of Planning and Transportation, 1994). Much of the AMG from such developments is likely to include masonry, bricks and slate tiles. Coal was the dominant fuel, consumed to heat homes and to power steam engines, creating significant quantities of ash waste.

During World War II (WWII) London was affected by significant building destruction during air raids (Ward, 2015), which commenced on 13 May 1940, and later from June 1944 to March 1945 through flying bombs (V1 and V2). AMG from this destruction is likely to include large quantities of brick, masonry and tiles, potentially unsorted personal objects not normally preserved when housing undergoes planned redevelopment, and extensive charring associated with fires. Evidence from OS historical maps show that areas recognised by Ward (2015) as 'totally destroyed' and 'damaged beyond repair', for example the Barbican Centre (Fig. 1), were redeveloped often on a completely different street pattern, making this a key time interval for the modern development of AMG in the City of London and Tower Hamlets boroughs.

\subsection{Key lithological changes that provide an indicator of age}

As discussed in Section 2.4, the nature of AMG can most directly be determined from borehole records. A substantial number of the borehole records refer simply to "made ground" or "fill", though many others contain information about the type of material (glass, ashes, bricks, cement, concrete, etc.) present into each layer. In places, clear stratification of the artificial deposits was recorded within boreholes. This section explains how the composition of certain distinctive materials within the 

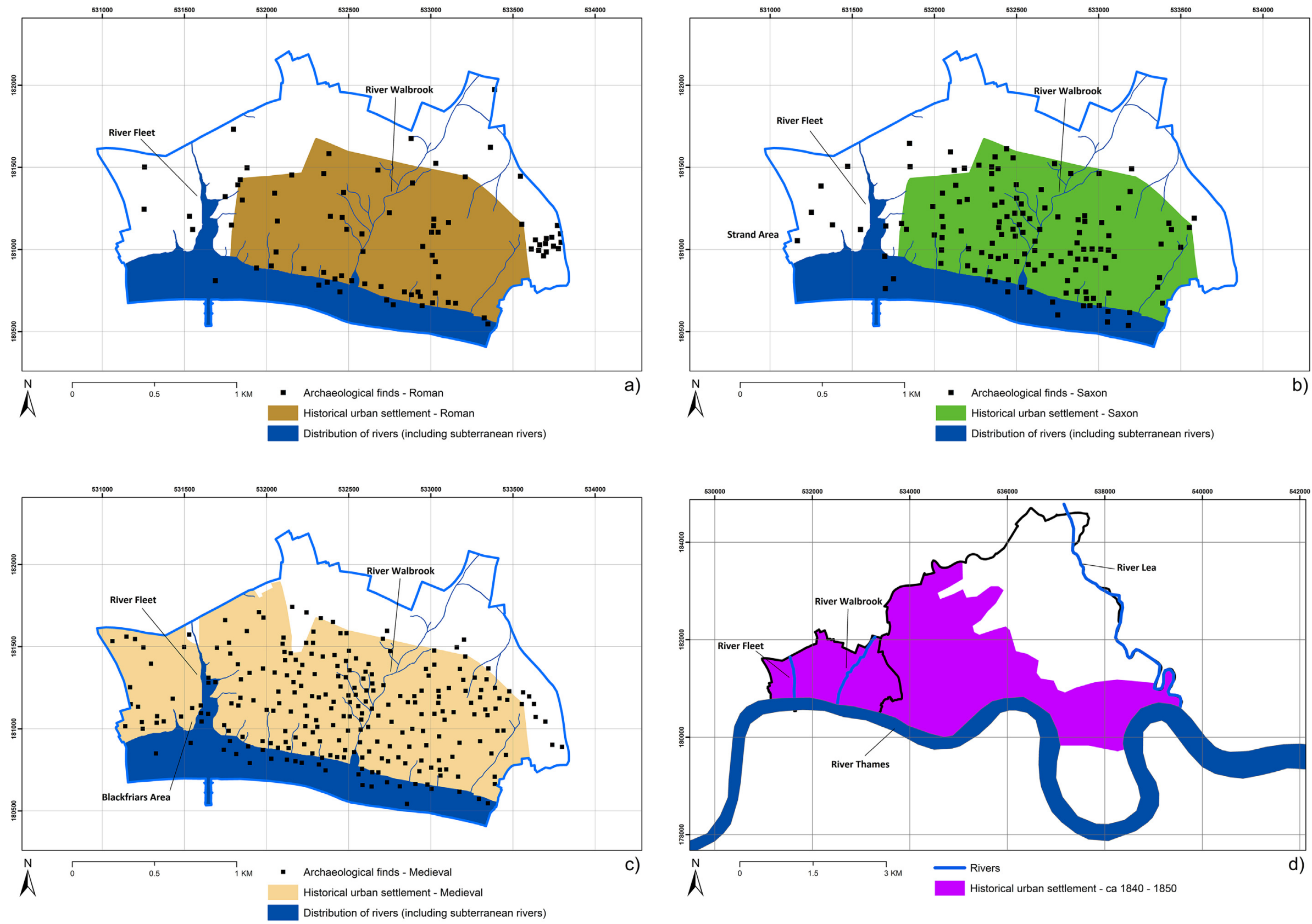

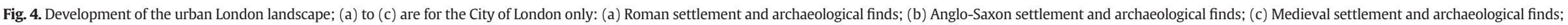

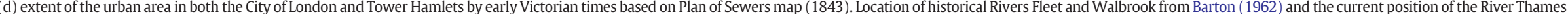
from OS Open Data (2017). Location of the city wall and archaeological finds were sourced from Brigham (2000). 
AMG can be used as a guide to the probable maximum age of a deposit (Table 2).

The clearest lithological distinction can be made between deposits that broadly coincide with post-WWII activity - a time interval that has been proposed to represent a new geological time interval known as the Anthropocene Epoch and that commences during the midtwentieth century 'Great Acceleration' in global growth in human population, consumption, trade and technological advances (Zalasiewicz et al., 2017b) - and with earlier successions including those associated with the Industrial Revolution. This section explains what lithological characteristics are used to classify borehole data into these two time intervals, as a means of determining the volumetric extent of deposits of Anthropocene age in comparison with the nearly $1900 \mathrm{yr}$ of precursor development and also allows attribution of the widespread anthropogenic change of the ground surface to either pre- or post- 1945 .

The Industrial Revolution was a time when it first became possible to extract large quantities of coal from deep underground workings and transport it to London, initially by canal and then by rail. The coal was used mainly in domestic fires for heating and by industries to generate steam power. The industrial usage of coal in London diminished markedly as oil and gas combustion became the fuel of choice from the mid-twentieth century onwards, though the local usage may have persisted in powering steam locomotives into the 1960s. The domestic use of coal fires was restricted in London in the 1950s through instigation of the Clean Air Act 1956 to limit development of thick smog. Hence, coal and the products of the burning of coal, such as ash and cinders (recorded in 637 incidences in boreholes, Table 2), provide a useful indication of age broadly (though not exclusively) coincident with the Industrial Revolution. Ash is particularly prevalent in boreholes present in parts of the City of London and close to the River Thames in Tower Hamlets in areas that at some stage have had industrial activity (see Section 4.3), the latter likely contributing through industrial burning of coal for power in the docklands, potentially even as waste from ship boilers.

Bricks have had a long duration as a principal building material and are found extensively in deposits across the study area (Fig. 5); the borehole dataset shows 2039 incidences of the presence of 'brick' (Table 2). Roman bricks are typically thinner and more crudely manufactured. By the mid-nineteenth century, Victorian architecture and utilities (such as railways, subways and sewage schemes) were increasingly using bricks as they could be manufactured cheaply and in bulk. Most of the housing stock up to WWII would have been constructed with bricks. Distinct brick forms and producer stamps should provide a good estimate of the age of the surrounding artificial deposits.

Table 2

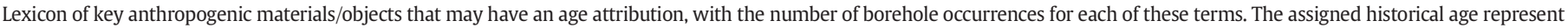
the most likely attribution, as used in this study.

\begin{tabular}{|c|c|c|c|c|c|}
\hline $\begin{array}{l}\text { Material name used in } \\
\text { borehole records }\end{array}$ & Land use interpretation & Age range & $\begin{array}{l}\text { Assigned } \\
\text { historical period }\end{array}$ & $\begin{array}{l}\text { City of London - } \\
\text { number of } \\
\text { occurrences }\end{array}$ & $\begin{array}{l}\text { Tower Hamlets - } \\
\text { number of } \\
\text { occurrences }\end{array}$ \\
\hline $\begin{array}{l}\text { Ash; ash/black; ash/charcoal; } \\
\text { ash/cinders; ash/soil; } \\
\text { ash/topsoil; ashes; ashy }\end{array}$ & $\begin{array}{l}\text { Product of coal burning, } \\
\text { domestic fires and steam boilers }\end{array}$ & $\begin{array}{l}\text { Probably pre-1960s; coal fires } \\
\text { banned in London in 1950s }\end{array}$ & Industrial Revolution & 55 & 480 \\
\hline $\begin{array}{l}\text { Asphalt; bitumen; bituminous; } \\
\text { blacktop }\end{array}$ & Road/footpaths & $\begin{array}{l}\text { First used on footpaths during the } \\
1830 \text { s in the UK }\end{array}$ & $\begin{array}{l}\text { Industrial Revolution; } \\
\text { Anthropocene }\end{array}$ & 3 & 64 \\
\hline Brick & Buildings/infrastructure/landfill & $\begin{array}{l}\text { First used in Roman times, but main } \\
\text { use was during nineteenth to early } \\
\text { twentieth century }\end{array}$ & $\begin{array}{l}\text { Roman; Industrial } \\
\text { Revolution; Anthropocene }\end{array}$ & 278 & 1761 \\
\hline Cast-iron & $\begin{array}{l}\text { Landfill/general; } \\
\text { waste/building }\end{array}$ & Mainly eighteenth century to present & Industrial Revolution & 0 & 2 \\
\hline Ceramic & Landfill/general waste & Roman to present & Unspecified & 5 & 156 \\
\hline China & Landfill/general waste & Nineteenth century to present & Industrial Revolution & 0 & 2 \\
\hline Coal & Fuel; industrial/housing & $\begin{array}{l}\text { Probably pre-1960s; coal fires } \\
\text { banished in London in 1950s }\end{array}$ & Industrial Revolution & 7 & 95 \\
\hline $\begin{array}{l}\text { Concrete; concrete/ash; } \\
\text { concrete/brickwork; } \\
\text { concrete/rubble; hard concrete; } \\
\text { lime concrete; concrete slab }\end{array}$ & Buildings/infrastructure/landfill & Likely post-1945 & Anthropocene & 254 & 1447 \\
\hline Ground/brickearth & Worked Ground- London Clay & Nineteenth century & Industrial Revolution & 0 & 1 \\
\hline Hard-core & $\begin{array}{l}\text { Made Ground of broken bricks, } \\
\text { stone or concrete }\end{array}$ & Post-1950 & Anthropocene & 6 & 31 \\
\hline Kerbstone & Pavement/roadway & 1760 s to present & $\begin{array}{l}\text { Industrial Revolution; } \\
\text { Anthropocene }\end{array}$ & 2 & 1 \\
\hline Lean; lean-mix & Relates to concrete & 1950 s to present & Anthropocene & 1 & 3 \\
\hline Manhole & Cover to utility services & 1850 s to present & $\begin{array}{l}\text { Industrial Revolution; } \\
\text { Anthropocene }\end{array}$ & 1 & 0 \\
\hline Nails & & Late eighteenth century to present & $\begin{array}{l}\text { Industrial Revolution; } \\
\text { Anthropocene }\end{array}$ & 1 & 7 \\
\hline Oil; oily & & Nineteenth century to present & $\begin{array}{l}\text { Industrial Revolution; } \\
\text { Anthropocene }\end{array}$ & 16 & 88 \\
\hline Plastic & Landfill/general waste & 1950 s to present & Anthropocene & 3 & 47 \\
\hline Porcelain & Landfill/general waste & 1700 s to present & $\begin{array}{l}\text { Industrial Revolution; } \\
\text { Anthropocene }\end{array}$ & 0 & 39 \\
\hline Sleeper & Railway land & 1836 to present & $\begin{array}{l}\text { Industrial Revolution; } \\
\text { Anthropocene }\end{array}$ & 1 & 4 \\
\hline Steel/steelwork & & Stainless since 1912 & $\begin{array}{l}\text { Industrial Revolution; } \\
\text { Anthropocene }\end{array}$ & 4 & 39 \\
\hline $\begin{array}{l}\text { Tarmac/tarmac/concrete/ } \\
\text { tarmacadam/macadam }\end{array}$ & Roadway & $\begin{array}{l}\text { First used on footpaths during the } \\
1830 \text { s in the UK }\end{array}$ & $\begin{array}{l}\text { Industrial Revolution; } \\
\text { Anthropocene }\end{array}$ & 43 & 84 \\
\hline Tile & Buildings & Roman to present & Unspecified & 16 & 40 \\
\hline Tins & Landfill/general waste & Post-1813 & $\begin{array}{l}\text { Industrial Revolution; } \\
\text { Anthropocene }\end{array}$ & 1 & 0 \\
\hline Wire & $\begin{array}{l}\text { Landfill/general } \\
\text { waste/buildings/services }\end{array}$ & $\begin{array}{l}\text { Roman to present; barbed wire } \\
\text { 1870s to present }\end{array}$ & $\begin{array}{l}\text { Industrial Revolution; } \\
\text { Anthropocene }\end{array}$ & 1 & 10 \\
\hline
\end{tabular}




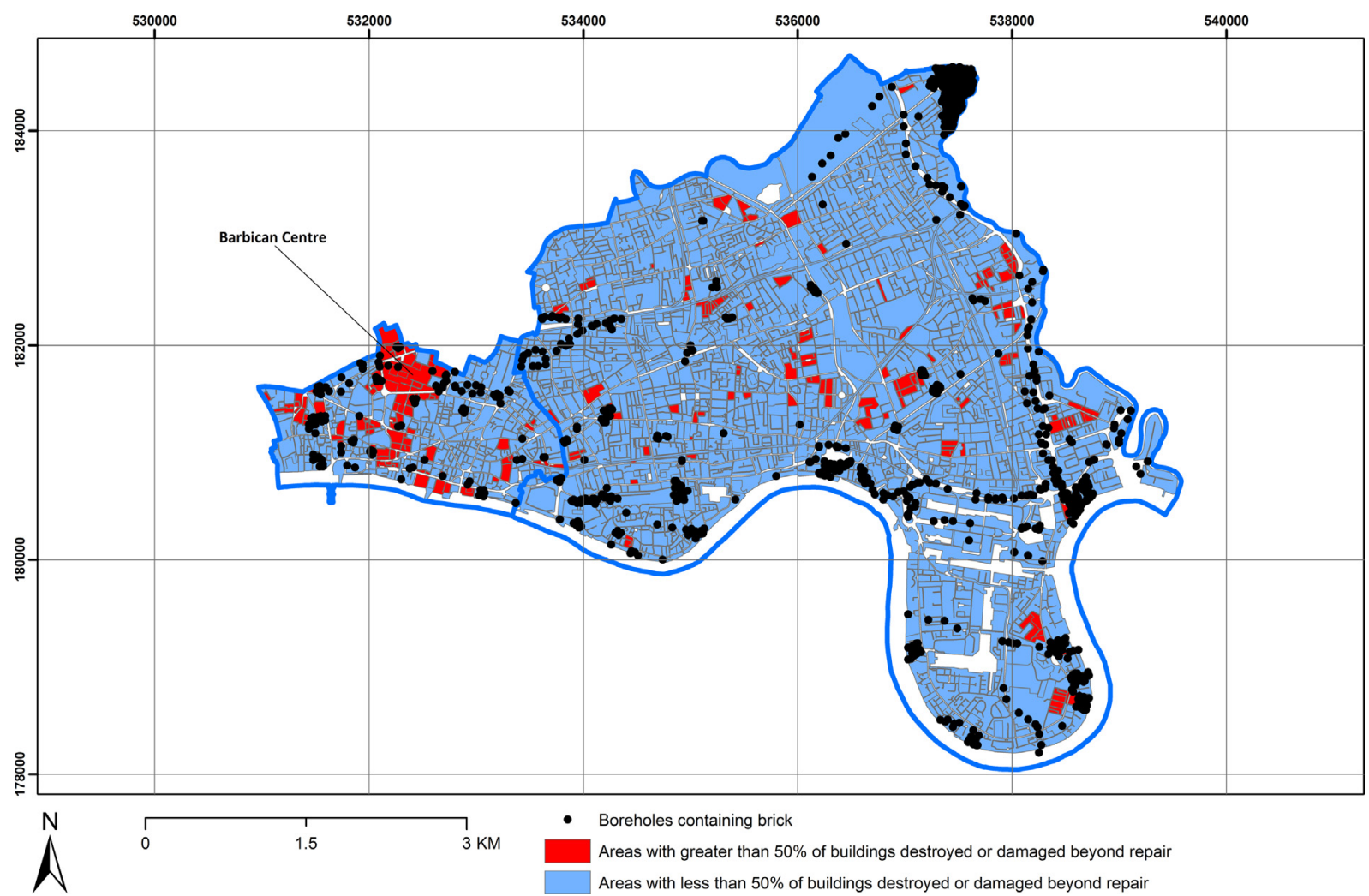

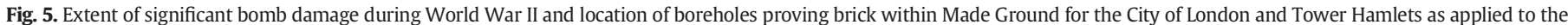
Urban Atlas.

Source: Bomb damage data modified from Ward (2015) (Urban Atlas - http://www.eea.europa.eu/legal/copyright).

However, information on the style and potential age of the bricks is not recorded in driller's logs and so only limited chronological information can be derived from their presence.

A hypothesis tested in this study is that the extensive areas of bomb damage during WWII (Fig. 5) are likely to be associated with much brick debris, potentially forming an event-horizon that broadly coincides with the start of the Anthropocene. Of the types of damage recognised by Ward (2015), those categorised as being 'totally destroyed' and 'damaged beyond repair' (Fig. 5) are selected in this study as marking the extent of sites most likely associated with abundant post-war redevelopment. This may be assumed to develop a debris layer rich in bricks, though boreholes that contain brick do not correlate with the areas of greatest bomb damage (Fig. 5). Bricks are most prevalent in boreholes present within areas of post-1945 development (Fig. 6). This was considered to reflect that Tower Hamlets was an area of extensive brick-built habitations prior to WWII and it is this area that has been extensively redeveloped, whereas many of the pre-WWII buildings in the City of London have historically been stone-built properties.

There is recognition that there is a poor correlation of the extent of brick debris (Fig. 5) with the main areas of bomb destruction. Furthermore, there appears to be little correlation between deposit thickness (Fig. 8a, b, c) and areas of most extensive bomb damage.

The poor correlation of AMG thickness and presence of brick debris may in part reflect the historic observation that much of the debris was transported to fill and raise the Lea Valley, immediately to the east of Tower Hamlets, and suggests little became incorporated into the foundations of subsequent buildings. A further possibility is that immediate post-war developments may not have been associated with rigorous site investigation and consequently relatively few boreholes penetrate the deposits of these redevelopment sites and their composition is therefore poorly known.

Concrete is present extensively in borehole records - 1701 incidences across the study area (Fig. 7 and Table 2) and is used in this study as a marker for the Anthropocene. As a building material it was developed by the Romans but it was during and after WWII that it became prolific in the construction of buildings; between 1995 and 2015 more than half of the 500 billion tonnes of concrete ever produced globally has been manufactured (Waters and Zalasiewicz, 2018). However, given the early Roman development of the material and possible small-scale usage in the early twentieth century, it is not always the case that concrete will indicate an Anthropocene age. For example, three boreholes drilled in 1910, 1913 and 1935 contain concrete that pre-dates Anthropocene deposits. Yet, for the vast majority of cases concrete would be expected to be a significant component of any demolition debris that occupies the foundations of subsequent constructions from the post-WWII phase of development (Figs. 6 and 7). There is a surprising abundance of concrete within parts of the City of London in which the dominant buildings pre-date 1945 (Fig. 6). In many cases this category reflects a change of building use - typically housing to commercial properties such as shops, restaurants or financial - but sufficient redevelopment has allowed concrete to become a common component of the AMG. Concrete is rarely proved in areas that maintained urban/residential status before and after WWII. In Tower Hamlets concrete and brick tends to be associated with areas that were industrial/commercial pre-WWII and continue to be so, or have converted to residential areas after WWII (Fig. 7).

It is surprising how few borehole logs mention the presence of plastic - 50 incidences in total (Table 2). It has become a ubiquitous component of manufactured materials; most of the main polymers currently in production were developed within a decade before and after 1950 and the global production has escalated from 1.7 million tonnes (Mt) in 1950 to 299 Mt in 2013 (Zalasiewicz et al., 2016). It is likely that the loggers describing the successions during the site investigations mentioned specific objects (e.g., bag, bottle, gutter, pipe, etc.) without indicating the material composition, resulting in significant underrepresentation. 


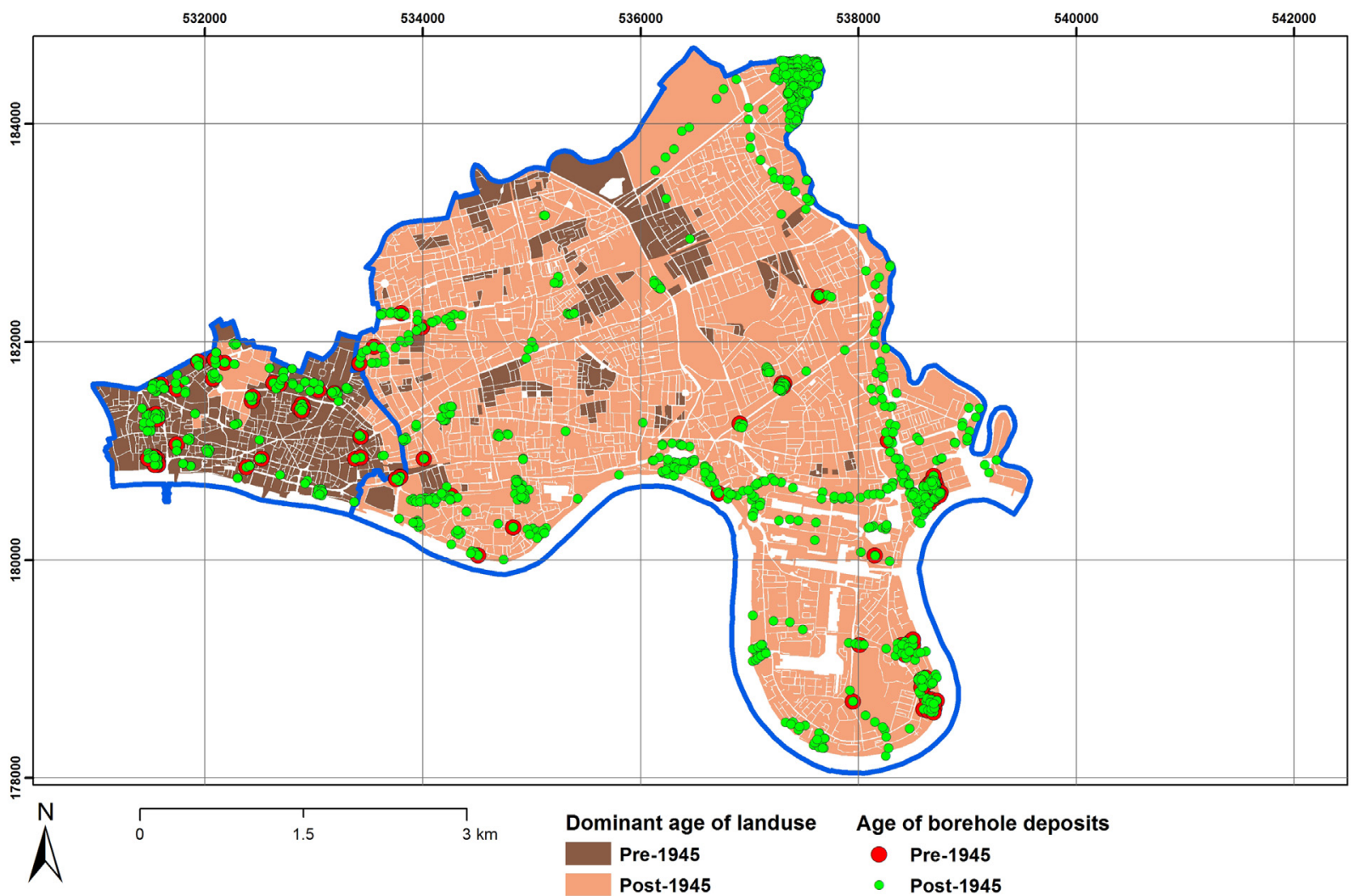

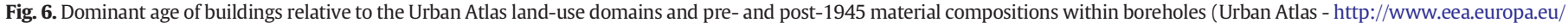
legal/copyright).

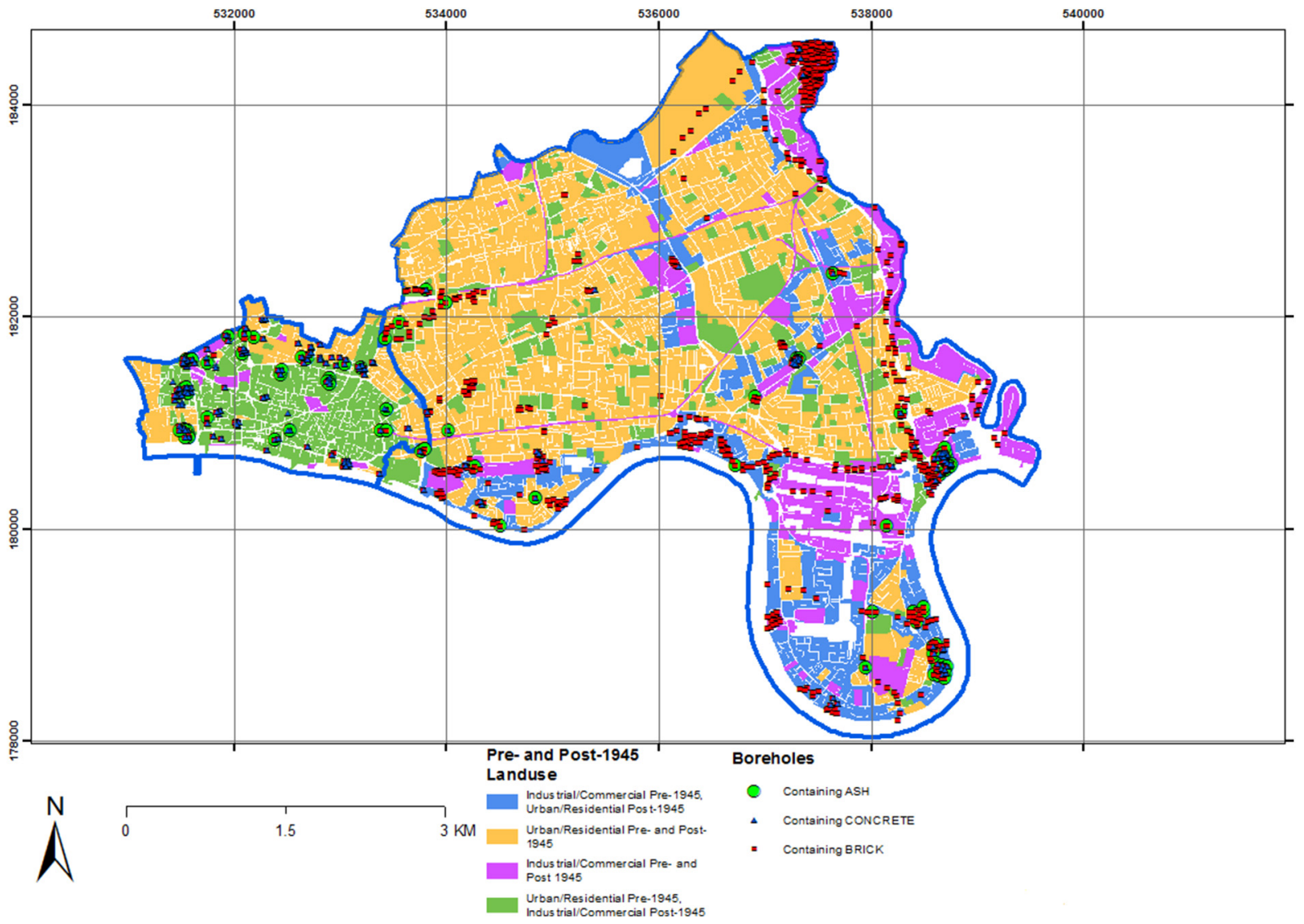

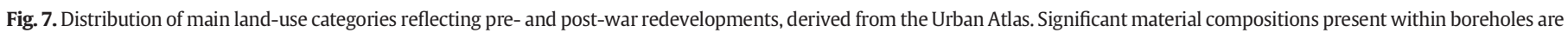
shown (Urban Atlas - http://www.eea.europa.eu/legal/copyright). 
In order to use the lithological compositions described above to provide an age attribution, some simple rules were followed:

- If the layer contains more than one material or object indicative of different periods, the youngest interval is chosen. For example, if coal and concrete are present, it is taken to be most likely an Anthropocene (post-WWII) deposit as this coincides with the main interval of concrete production and usage. Coal is less likely to have been deposited during the Anthropocene, but the process of accumulation of the deposit may have disturbed and reworked underlying coal-bearing materials. Therefore, the true age should be determined by the youngest component.

- Where more than one layer is present in the deposit, if a higher layer contains materials or objects indicative of an older age than an underlying layer, the law of superposition states that the higher unit should be younger. For instance, if a lower layer contains plastic (i.e., inferred Anthropocene age) and the overlying unit contains ash/cinders (i.e., inferred Industrial Revolution age), the upper layer is attributed with the younger age. Ash/cinders, although significantly less common in the Anthropocene in London, could still be deposited locally during this interval, or could represent local excavation and redeposition of older deposits to create an apparent inverted stratigraphy; the possibility that the younger deposit could represent infill within subterranean excavations was discounted unless described as such by the loggers. The same methodology was taken where the higher layer lacked age-diagnostic materials, such as sand and gravel.

The post-WWII interval aligns with the globally proposed Anthropocene geological epoch, a time that represents significant modification of urban landscapes across the planet and production of novel materials, including plastic and aluminium, and great expansion in the production of other materials, most notably concrete (Waters et al., 2016). Most of the buildings in Tower Hamlets post-date 1945 ( $85 \%$ of aerial extent), compared with $12 \%$ in the City of London, which retains a greater number of heritage buildings (Fig. 6). Canary Wharf, in Tower Hamlets, has seen significant redevelopment post1945 as London became one of the most important financial and business centres in the world. Immediate post-war development saw the previous fashion for building using brick and Portland stone replaced by concrete and glass, driven in part by a need for rapid construction of new housing stock and public buildings. The pace of redevelopment means that there has already been considerable turnover of post-war buildings, notably to install high-rise tower blocks and infill of some of the docklands to generate additional land for building. The Anthropocene is also noted as a time of increased use of the subsurface as earthworks for habitation, transportation and utilities, boreholes, tunnels and caverns, waste and resource storage facilities (Zalasiewicz et al., 2014), although London was at the forefront of such urban development in that subway and sewage tunnels became extensive from as early as the mid-nineteenth century.

\subsection{Categories of land use and their modification in extent during the} nineteenth to the twenty-first centuries

An understanding of current and former land use provides useful information on the likely nature of the underlying AMG, particularly where the land use generates waste. Land-use categories were derived from phases of historical Victorian Ordnance Survey (OS) maps ranging from 1882 to 1898 and modern OS data from 2015 (see Section 2.2). For the purposes of this study the land use has been divided into two broad domains based on the Urban Atlas classification of urban land use (Fig. 7):

- Urban/Residential: building in which the primary purpose is for inhabitation and includes private gardens;
- Industrial/Commercial: restaurants, hotels, public houses, shops, markets, petrol stations, banks, and other financial organisations and offices. Warehouses, factories and dockyards.

The City of London currently has a ratio of 33 times more workers than residents (determined to be $~ 8000$ in 2011 (https://www. cityoflondon.gov.uk/things-to-do/visit-the-city/our-history/Pages/cityhistory.aspx\#), hence the low areal extent of the Residential (31\%) category. Tower Hamlets contains a greater proportion of residential housing (72\%) associated with an estimated population in mid-2014 of 284,000. In the City of London, outside the areas of extensive bomb damage, e.g., the Barbican Centre (Fig. 5), the street patterns from the late nineteenth century have been broadly maintained through to the present day, although the land use of the buildings shows a marked change towards offices. Tower Hamlets has undergone more extensive redevelopment, particularly associated with the modern Docklands and Canary Wharf developments. Trends in compositional variation of deposits associated with land-use categories are described in Section 4.2.

\section{Volume of artificially modified ground}

This section provides a methodology for estimating the total volume of artificial ground present in the study area. It also explores the extent to which heterogeneity in AMG thickness is controlled by the proximity to the River Thames and variation in underlying geology.

\subsection{Methodology for determining AMG thickness and volume from borehole records and digital terrain models}

The thickness of AMG can be directly determined from borehole records (Section 2.4). The depth of the boundary between a natural and an anthropogenic deposit - the Boundary A or base of the archaeosphere of Edgeworth et al. (2015) - is determined relative to the level of the ground surface at the time of the site investigation to provide the AMG thickness in each borehole. After the AMG thickness map (Fig. 8a) is produced, the data are interpolated using kriging to provide minimum, maximum, and mean thickness and standard deviation related to each Urban Atlas area domain (Table 3). From this a direct comparison of AMG thickness and volume against numerous parameters, including land use, building heights, age of buildings, and dominant type of underlying geology, can be made per Urban Atlas polygon.

It is important to realise that commonly the boreholes were drilled in advance of site redevelopment and the surface elevation at the borehole location may have been modified by subsequent development. Borehole start heights allow estimation of the thickness of AMG that has been either deposited or removed since the time of drilling. Comparison of modern day ground surface level (LiDAR DTM, 2006) and the historical start heights of boreholes, i.e., the elevation of the borehole when it was drilled, provides an approximation of anthropogenic ground surface increase (Made Ground) or decrease (Worked Ground) and shows what the landscape looked like before the geometry of the surface was modified (Terrington et al., 2015). These comparisons can be used in addition to those boreholes that have AMG recorded to show artificial landscape evolution where areas have been filled or worked, or both in some cases. In Fig. 2 the start height (ground level) is recorded as $4.75 \mathrm{~m}$. In some circumstances, boreholes can be drilled from a sub-surface position or with a reference level that relates to an elevated position on the drill rig, thus it is important to remove such records from the study unless datum levels are known. Not all boreholes record start heights at the time of drilling, in which case it is necessary that they are attributed with one using the modern digital terrain model (DTM), which shows current ground elevation levels.

Table 3 demonstrates the differences in AMG thickness and volumetric data when (i) using borehole AMG thickness data alone and (ii) incorporating the additional estimated AMG - interpolated using 

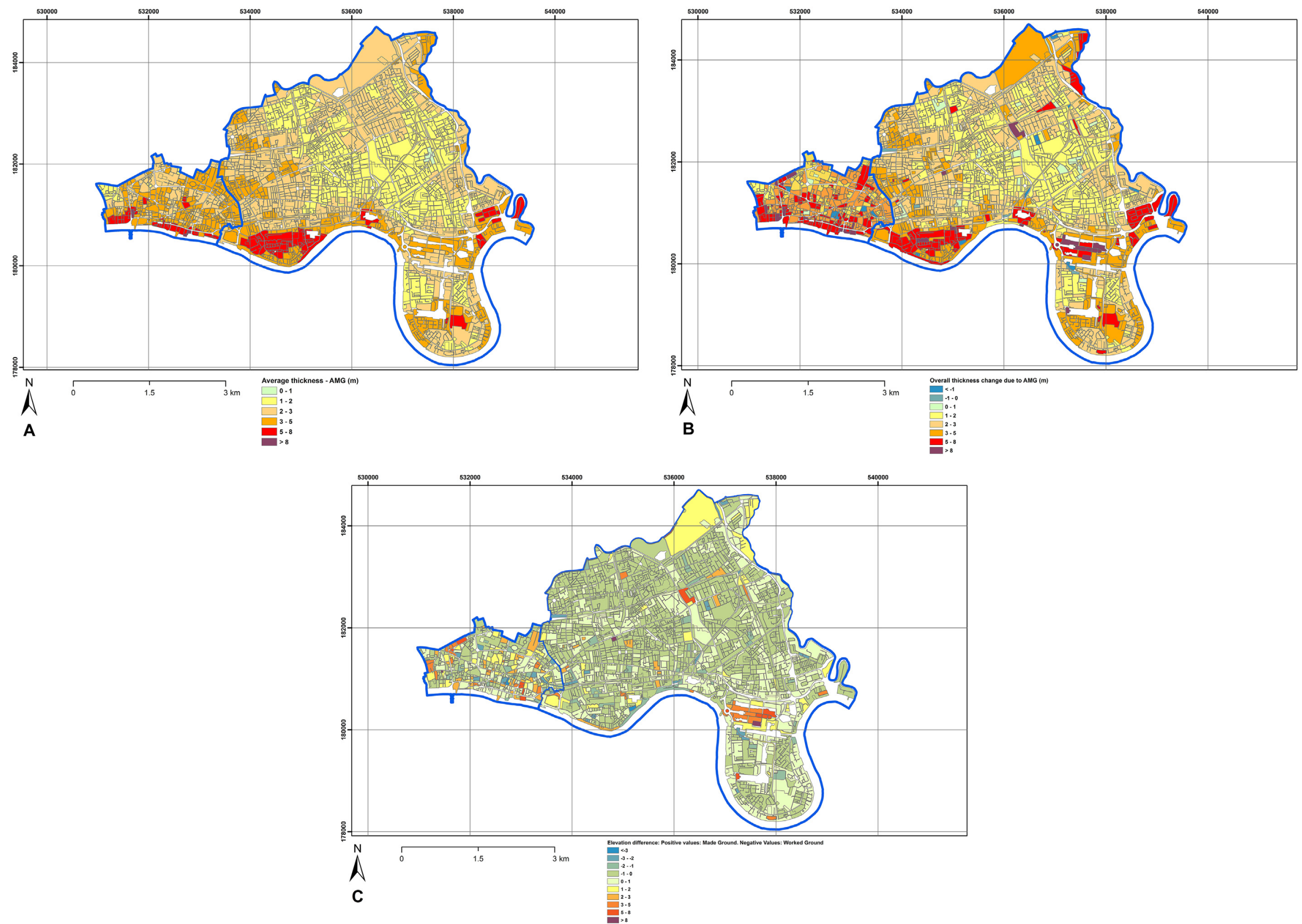

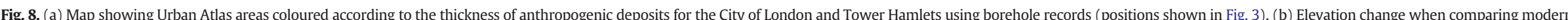

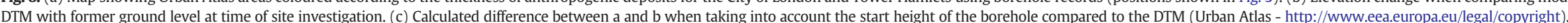


Table 3

Thickness and volumetric data for AMG in the City of London and Tower Hamlets.

\begin{tabular}{|c|c|c|c|c|}
\hline & Maximum thickness (m) & Mean thickness (m) & Standard deviation & Subsurface volume $\left(\mathrm{m}^{3}\right)$ \\
\hline City of London (borehole thickness only) & 8.44 & 3.37 & 1.18 & $10,615,500$ \\
\hline City of London (with elevation change) & 10.91 & 3.74 & 2.23 & $11,781,000$ \\
\hline Tower Hamlets (borehole thickness only) & 7.61 & 2.47 & 1.02 & $53,277,900$ \\
\hline Tower Hamlets (with elevation change) & 13.52 & 2.54 & 1.4 & $54,787,800$ \\
\hline
\end{tabular}

the previous start height and the modern DTM - deposited during site redevelopment.

The mean thickness of AMG for the City of London is $3.37 \mathrm{~m}$ and Tower Hamlets is $2.47 \mathrm{~m}$; when including the start height adjustment against the modern DTM the thickness is slightly greater for the City of London $(3.74 \mathrm{~m})$ compared with Tower Hamlets $(2.54 \mathrm{~m})$ (Table 3). These thicknesses are significantly greater than the average value of $1.6 \mathrm{~m}$ proposed by Ford et al. (2014) for Greater London. The thicker values within the City of London may be attributed to the longer history of development stretching back to Roman occupation, whereas much of Tower Hamlets was more recently developed in the nineteenth century. Comparison of the start height levels at the time of site investigation with the modern DTM suggests that for most of both the City of London and Tower Hamlets there has been additional material deposited post-site investigation (Fig. 8b). The greatest disparities are in those areas where AMG is thickest within the borehole records and where there have been large-scale developments, for example in Canary Wharf. This has moderated the general pattern of large areas of Worked Ground, where the land has been skimmed for new construction (Fig. 8c).

When multiplying the area $\left(\mathrm{m}^{2}\right)$ against the mean thickness of the AMG deposits recorded in the boreholes, the volume of AMG deposits was estimated at 10.6 million $\mathrm{m}^{3}$ for the City of London and 53.3 million $\mathrm{m}^{3}$ for Tower Hamlets. However, when taking into account the interpolated start height difference against the modern DTM, the revised volume of AMG material increases in both areas - 11.8 million $\mathrm{m}^{3}$ and 54.8 million $\mathrm{m}^{3}$, respectively (Table 3 ). For the City of London, the total revised volume is the equivalent of three filled Wembley stadiums or 4700 Olympic-sized swimming pools; in Tower Hamlets this is the equivalent of 13.5 Wembley stadiums or nearly 22,000 Olympic-sized swimming pools. Some of this AMG volume will have been moderated through the removal of material as Worked Ground but, as Table 3 demonstrates, the dominant trend is for AMG to increase surface elevation, and therefore AMG volume, with time. For the City of London, an increased AMG volume of $\sim 11 \%$ is estimated when taking into account the start height adjustment; for Tower Hamlets, the additional volume is an increase of only $3 \%$. The greater degree of change in apparent post-site investigation thickness of AMG in the City of London suggests that redevelopment is more intensive within its much smaller area compared with Tower Hamlets.

\subsection{Relationship between artificial modified ground thickness and proximity to the River Thames}

Medieval AMG deposits lining the Thames and in the Fleet and Walbrook valleys have been recorded up to $4 \mathrm{~m}$ thick, and up to $6 \mathrm{~m}$ thick below today's modern street level on some waterfront sites (Department of Planning and Transportation, 1994), which was considered above average for the City of London. This has been supported by the current study, which finds that the distribution of the thickest anthropogenic deposits is concentrated along the flank of the River Thames and its tributaries (Fig. 8). This section considers the extent that close proximity to a river could be the cause of the increased thickness of AMG, and that these elevated thicknesses can be extrapolated along the whole length of the main river and tributaries (Figs. 1 and 8 ). This was investigated by determining the average thickness of deposits both less than and $>500 \mathrm{~m}$ from the River Thames, which is the distance that encompasses most of the recent Holocene alluvial deposits in the Thames floodplain. This does not take into account subterranean tributary rivers, such as the Fleet and Walbrook in the City of London and the River Lea in Tower Hamlets, which can also be associated with greater thicknesses. Both boroughs show an appreciable decrease in thickness away from the river; the combined mean of $3.7 \mathrm{~m}$ within the neighbourhood of the River Thames reduces to $2.4 \mathrm{~m}$ beyond (Table 4). A long history of land reclamation has occurred along the River Thames and the many tributaries that have been culverted, such as the Fleet and Walbrook (Fig. 4d), and these results support the increase of AMG thickness in these areas. The increased thicknesses represent construction of flood embankments or built up areas to raise the buildings above the level of the water courses and potential flooding (Barton, 1962).

\subsection{Relationship of thickness to underlying geology}

The southern part of the study area is underlain by natural floodplain deposits (alluvium) of the River Thames and tributaries of the rivers Fleet, Walbrook and Lea (Fig. 9). The alluvial tract of the River Thames, now buried beneath AMG, falls from an elevation of approximately 4$6 \mathrm{~m}$ above ODN (Ordnance Datum Newlyn) to the west of the area in Westminster to 2-5 $\mathrm{m}$ above ODN in the east around Blackwall. Silt and organic deposits (peat) are likely to be a significant component of these deposits, and have the potential of being associated with compaction and drying, and hence ground instability. Peat has been noted and included as a lithological layer within the alluvium and some of the terrace deposits in the superficial and bedrock geological model of the London Basin (Burke et al., 2014), although these organic deposits have not been modelled individually. To the north of the area of alluvium, the AMG is underlain by an extensive area of river terrace deposits, representing older and elevated tracts of river gravels associated with former positions of the River Thames during the Pleistocene. The Langley Silt Member (formerly Brickearth) locally rests upon these river terrace gravels, comprising yellow-brown silt to clay. This deposit averages $3 \mathrm{~m}$ in thickness in London, but has recorded thicknesses of $6 \mathrm{~m}$ according to the London and Lower Thames Valley geological model (Burke et al., 2014) and sits directly above terrace gravel deposits, in this case the Taplow gravel and Kempton Park gravel members (Gibbard, 1995; Rose et al., 2000). In the City of London, notably adjacent to the River Fleet, small areas of the London Clay Formation crop out beneath the AMG. This clay-dominated unit is known to be prone to shrink-swell (Jones and Terrington, 2011).

The AMG thickness data (Fig. 8) can be statistically correlated with the immediately underlying non-anthropogenic geology (Fig. 9 and Table 5). The strongest correlation is for the thickest developments of AMG to occur in areas underlain by former alluvium, present beneath

Table 4

The variation of thickness of AMG within a distance of $500 \mathrm{~m}$ of the River Thames and areas outside of this distance.

\begin{tabular}{lll}
\hline & $\begin{array}{l}\text { Mean AMG thickness }(\mathrm{m}) \\
\text { within 500 m of River Thames }\end{array}$ & $\begin{array}{l}\text { Mean AMG thickness }(\mathrm{m}) \\
>500 \mathrm{~m} \text { away from River Thames }\end{array}$ \\
\hline City of London & 3.81 & 3.31 \\
Tower Hamlets & 3.45 & 2.27 \\
Combined & 3.72 & 2.42 \\
\hline
\end{tabular}



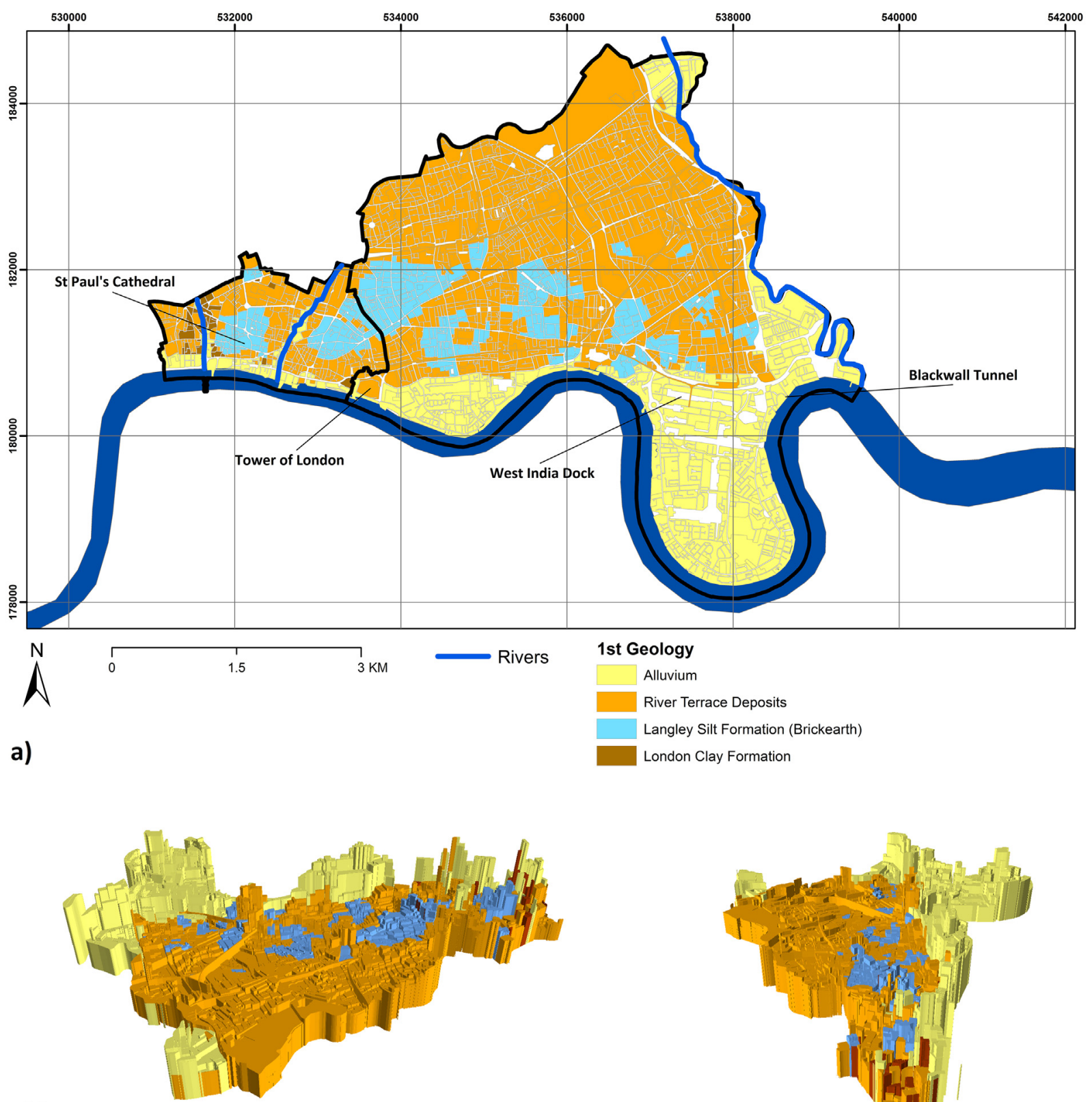

b)

C)

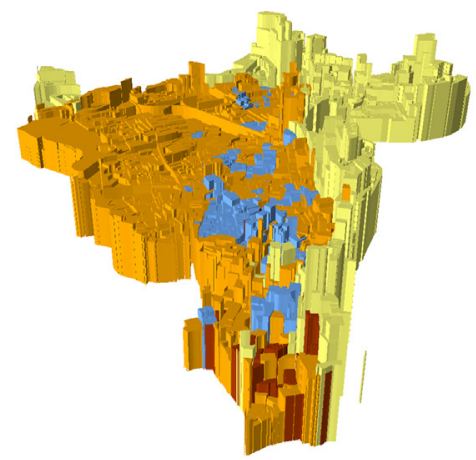

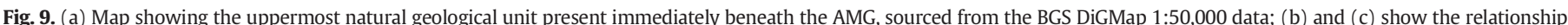

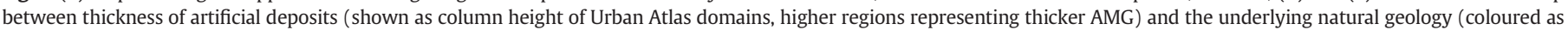
for Fig. 9a). Fig. 9b looking towards the south and Fig. 9c to the east (Urban Atlas - http://www.eea.europa.eu/legal/copyright).

floodplains associated with the rivers Walbrook, Fleet and Thames. It is in these areas that archaeological artefacts are most likely to be found; in particular well-preserved Roman remains (Fig. 4a). The floodplains of the Walbrook and Fleet have been, for the most part, altered, vaulted and built up to be largely infilled as has part of the channel of the River Thames along Victoria Embankment, constructed in 1864-1870. The ground has been considered to have been elevated to modern street

Table 5

Thickness of artificial deposits relative to first underlying natural superficial deposit.

\begin{tabular}{lllll}
\hline & Alluvium & Terrace deposits & Langley silt & London clay \\
\hline City of London & $5.53 \mathrm{~m}$ & $3.19 \mathrm{~m}$ & 3.84 & 4.33 \\
Tower Hamlets & $3.65 \mathrm{~m}$ & $2.21 \mathrm{~m}$ & $2.37 \mathrm{~m}$ & $\mathrm{~N} / \mathrm{A}$ \\
\hline
\end{tabular}

level by around $7.6 \mathrm{~m}$ along the Fleet and around $10 \mathrm{~m}$ along the Walbrook (Barton, 1962), though the current study suggests that elevations will have broadly increased since that analysis more than half a century ago.

There are also clusters of thicker anthropogenic deposits in areas underlain by brickearth geology (Langley Silt Member), particularly in the area between the Walbrook and Fleet tributaries. This is possibly associated with areas of excavation and subsequent backfill during brick manufacturing, which has been exploited over a long period of time as a resource in this area (Gibbard, 1995). Furthermore, this deposit would have been removed altogether to access the underlying aggregate resource and then backfilled, which would have resulted in greater thicknesses of AMG, a significant Anthropogenic modification to the landscape showing Worked Ground, and Worked and Made Ground. It may also correspond to a bomb damaged area located 
Table 6

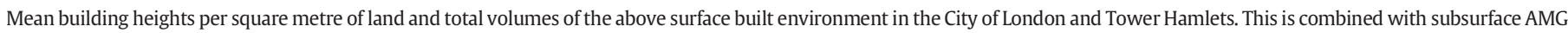

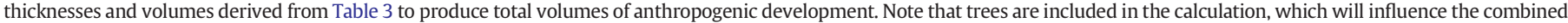
average taken from the DSM.

\begin{tabular}{|c|c|c|c|c|}
\hline & $\begin{array}{l}\text { Mean building } \\
\text { elevation }(\mathrm{m})\end{array}$ & $\begin{array}{l}\text { Volume above } \\
\text { ground surface }\left(\mathrm{m}^{3}\right)\end{array}$ & $\begin{array}{l}\text { Combined average of above surface building } \\
\text { and AMG volume }\left(\mathrm{m}^{3}\right) \text { per } \mathrm{m}^{2}\end{array}$ & $\begin{array}{l}\text { Total volume above and } \\
\text { below surface }\left(\mathrm{m}^{3}\right)\end{array}$ \\
\hline City of London & 13.63 & $42,934,500$ & 17.37 & $54,715,500$ \\
\hline Tower Hamlets & 14.63 & $315,569,100$ & 17.17 & $370,356,900$ \\
\hline
\end{tabular}

north and northwest of St. Paul's Cathedral (see Fig. 5). The greatest thicknesses of AMG are the areas of Infilled Ground in former docks in Tower Hamlets, with up to $13.5 \mathrm{~m}$ of deposits recorded infilling the former West India Export dock basin.

\section{The built environment and relationship to anthropogenic deposits}

This section considers the extent that building volumes add to the compaction of geological strata, including AMG, and the possibility that they may exert a control on the thickness of AMG.

\subsection{Calculation of the combined above surface built environment and AMG volumes}

The DSM was used to estimate a total volume of space occupied by the above surface built environment (i.e., building volumes) (Table 6). This was combined with the thickness of subsurface AMG to give a total volume of space taken up by anthropogenic development in the City of London and Tower Hamlets boroughs (Table 6 and Fig. 8). This was calculated by averaging the DSM height across the Urban Atlas areas, and then multiplying the average height against the total area of that polygon. The combined volume of above surface building and below surface AMG can be averaged out per square metre of land for the City of London and Tower Hamlets areas. This method for deriving building height has issues where there are significant areas of tall vegetation that would influence the average height calculated per Urban Atlas Area.

The values in Table 6 show that building height is typically greater than the thickness of the underlying AMG; for the City of London on average 3.6 times greater and for Tower Hamlets 5.7 times greater. The close similarity in the total thickness of anthropogenic development $(\sim 17 \mathrm{~m})$ between the boroughs reflects that the City of London has a greater mean thickness of AMG, a consequence of the much longer duration of historical use of the subsurface, but typically lower buildings; in contrast Tower Hamlets typically has slightly higher average elevation of buildings but thinner AMG.

\subsection{Relationship of building height to thickness of artificially modified ground and underlying geology}

One would expect that average excavation depth increases with time, a relationship recognised as the consequence of the increasing presence of higher buildings, greater number of underground garages and more utilities (Rivas et al., 2006). It may be expected that the tallest buildings should have the thickest artificial deposits below them, related to their construction on deeper foundations. Many high-rise developments in Tower Hamlets, e.g., Canary Wharf and Blackfriars, do show the anticipated positive relationship between building height and AMG thickness (Fig. 10). However, especially in the City of London there is an apparent inverse relationship between building

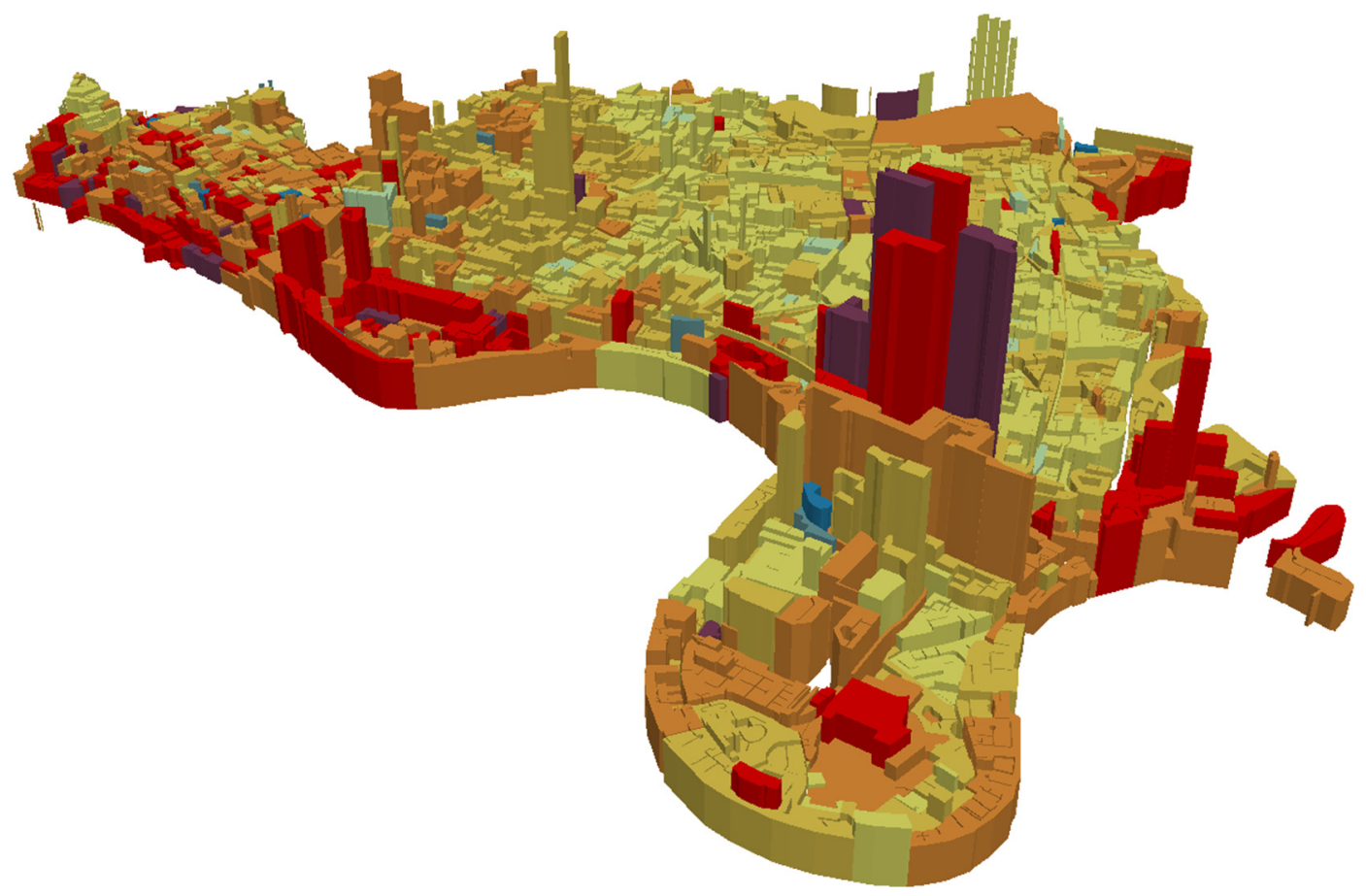

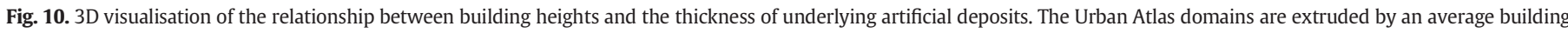

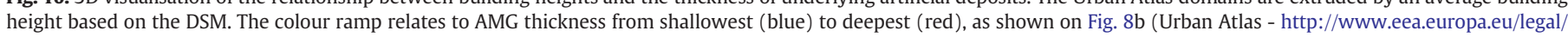
copyright). 
height and thickness of underlying artificial deposit. At present, three features have been found to explain why this is the case:

- River floodplains show the greatest thickness of anthropogenic deposits, much of which is associated with the construction of river walls, sewage tunnels, bridges, and culverting of the rivers Fleet and Walbrook, mostly predating the construction of the current buildings. The tallest buildings are, probably for planning reasons, not located along the river front (Fig. 10).

- The anthropogenic deposit thickness map (Fig. 8a) is produced through the interpolation of borehole data. However, not all buildings have available borehole data, in which case the anthropogenic deposit thickness below is interpolated from data available from adjacent urban land-use domains derived from the Urban Atlas (2010). For example, no boreholes were available for St. Paul's Cathedral, but numerous boreholes were present in the vicinity. Also, modern and typically taller buildings are probably more likely to have borehole data, which may result in an over-estimate of mean building height. There is an assumption in the modelling that the thickness changes gradually and predictably, whereas true foundation depths are likely to be specific to particular tall buildings.

- Borehole drilling is carried out, in general, as part of a site investigation to determine the nature of foundation conditions in advance of the construction of the building. As such, the borehole data records a history of the artificial deposits before they were potentially modified through reshaping, removal or addition of further material on to the site. It may not record the current nature and thickness of the AMG at the site. This problem is overcome when the thickness of deposits is estimated using the modern DTM (Fig. 8b), but this does not change the overall observation of poor correlation of deposit thickness and building height.

\section{Distinction of volumes of pre- and post- mid-twentieth century anthropogenic materials}

Due to the reworking of similar materials since the Roman times, using AMG composition to distinguish between different age periods is problematic. However, ash (primarily existing pre-1945) and concrete (mainly post-1945) can be selected as distinct markers for identifying a key divide between the historical development and the rapidly expanding modern landscape of the City of London and Tower Hamlets (see Section 4.2). This section shows how the location, depth, and type of materials found in the boreholes can be used to ascertain the potential evolution of the land use and give an estimate of the accretion rate of AMG.

The separation of AMG deposits into these two distinct age intervals shows the extent that post-1945 development has generated artificial deposits across most of the study area (Fig. 11a). The proportions of pre-/post-1945 thicknesses (Table 7) can be related to the total volumes as shown in Table 3 to calculate the estimated volume of pre-/post-1945 AMG. The average thicknesses for pre-/post-1945 deposits are calculated independently using a subset of the boreholes that show the greatest likelihood of including both pre-/post-1945 deposits. The calculations do not take into account any start height elevation factors compared to the modern terrain model.

Those deposits that broadly align with the proposed Anthropocene Epoch (i.e., post-1945) are quantified as representing 37\% of the total volume of deposits in the City of London and $44 \%$ for Tower Hamlets (Table 7). In Tower Hamlets the distribution of borehole data is irregularly clustered, especially concentrated along linear transport routes (Fig. 8a). Despite this, a rough estimate of pre-/post-1945 AMG thickness can be calculated and mapped directly from the boreholes that show evidence of both pre-/post-1945 AMG, as shown in Fig. 11a and $\mathrm{b}$, and the accretion rate estimated for post-1945 AMG deposits (Table 8). Over the last $72 \mathrm{yr}$ (1945-2017), the average AMG accretion rate is $19.2 \mathrm{~mm} \mathrm{yr}^{-1}$ for the City of London and $15.5 \mathrm{~mm} \mathrm{yr}^{-1}$ for Tower Hamlets.

This accretion of post-1945 deposits is likely to comprise two complexly interrelated processes. There will be a component of reworking of the pre-existing artificial deposits through excavation and movement (either internally or externally relative to the development site). If this entailed incorporation of new materials, the deposit is given a post1945 attribution. It is likely that some modification of pre-1945 deposits has occurred but cannot be recognised in the boreholes because of the absence of typical post-1945 materials (Table 2). Consequently, it is suggested that the volume of post-1945 deposits is a minimum estimate. The second component will be an addition of entirely new materials, perhaps from post-1945 demolition of former buildings occupying a site or through importing of new foundation materials, which results in an increased elevation of ground surface. To determine the true accretion rate with time it is necessary to consider only the second component. This can be estimated by relating historical elevations shown in borehole records against the current DTM (Fig. 8b).

Fig. 12 shows the dominant age of the AMG calculated from the proportion of the thickness of the pre-/post-1945 AMG deposits as identified in Table 7. Deposits with $>50 \%$ of post- 1945 AMG thickness are limited in extent in both areas, though they are common in the northeast of Tower Hamlets.

The results of this division of pre-/post-1945 deposits, when visualised in 3D, show that pre-1945 deposits dominate along the River Thames, most clearly seen when looking to the north and particularly in the City of London area (Fig. 13a). In contrast, looking from a north to south direction pre-/post-1945 deposits seem more evenly distributed (Fig. 13b). There are clustered areas of either dominantly pre-1945 or post-1945 deposits (Fig. 13a and b), which is more of an indication of the borehole data that was available to determine the thickness of AMG in these areas rather than definitive estimations of the proportions of pre-/post-1945 deposits.

\section{Discussion}

Having produced estimates for the volumes for both the below ground AMG and above ground built environment, this section attempts to quantify the mass of the combined anthropogenic impacts for the study area and provides a process by which comparable figures for the entire area of Greater London can be estimated. It also considers the extent that local variations in the mass of both buildings and underlying deposits may cause differential compaction and settlement.

\subsection{The mass of buildings and AMG within the study area and AMG} extrapolated across London

This study provides an estimate of the mean thickness and volume of AMG (Section 5.1) and the built environment (Section 6.1) within the study area. Attempting to estimate the mass of both components is open to considerable uncertainties. Buildings show markedly different densities based on their dominant construction materials and design, in particular the amount of open void. Similarly, AMG is likely to change in density depending upon the composition and degree of compaction of the deposits. In both cases, the necessary parameters to make such determinations are not available, but generalisations can be made.

First, the mass of anthropogenic deposits can be obtained by multiplying the total AMG volume (Table 3 ) by $1.5 \mathrm{t}$ per $\mathrm{m}^{3}$, which is the approximate density of sand and gravel, crushed rock or soil, here considered comparable to anthropogenic materials (Edgeworth et al., 2015; Zalasiewicz et al., 2017a). This provides an estimate of $15.9 \mathrm{Mt}$ of AMG in City of London and 79.9 Mt for Tower Hamlets, based upon borehole data alone, or $17.7 \mathrm{Mt}$ and $82.2 \mathrm{Mt}$, respectively, when modelling in surface elevation from the DTM. Hooke (2000) provides historical estimates of the mass of earth moved during the growth of London, increasing markedly from $0.9 \mathrm{Mt}$ from 350 to $250 \mathrm{yr}$ ago to $13 \mathrm{Mt}$ from 

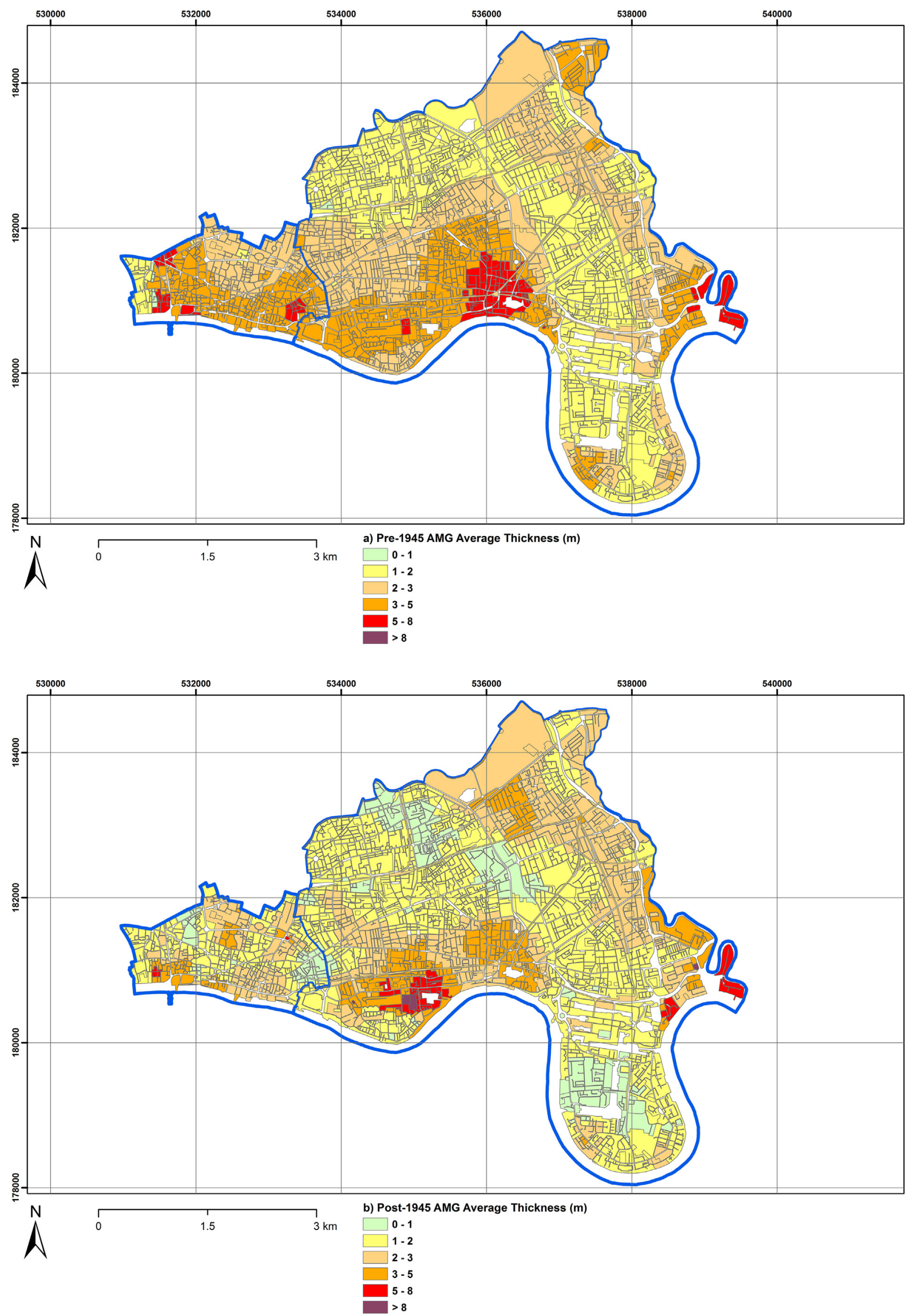

Fig. 11. AMG thickness from boreholes, categorised by age (a) pre-1945 and (b) post-1945. 
Table 7

Estimation of the thickness of pre-/post-1945 AMG deposits.

\begin{tabular}{lllll}
\hline & $\begin{array}{l}\text { Pre-1945 } \\
\begin{array}{l}\text { average } \\
\text { thickness }(\mathrm{m})\end{array}\end{array}$ & $\begin{array}{l}\text { Post-1945 } \\
\text { average } \\
\text { thickness }(\mathrm{m})\end{array}$ & $\begin{array}{l}\text { Proportion } \\
\text { of AMG } \\
\text { pre-1945 (\%) }\end{array}$ & $\begin{array}{l}\text { Proportion } \\
\text { of AMG } \\
\text { post-1945 (\%) }\end{array}$ \\
\hline City of London & 3.2 & 1.88 & 63 & 37 \\
Tower Hamlets & 2.51 & 1.94 & 56 & 44 \\
\hline
\end{tabular}

Table 8

Volume calculated from the proportion of pre- and post-1945 thicknesses (see Table 3 for total volume estimates incorporating elevation change from the DTM and differential to borehole start heights) and accretion rate during the Anthropocene Epoch.

\begin{tabular}{llll}
\hline & $\begin{array}{l}\text { Volume estimate of total } \\
\text { thickness pre-1945 }\left(\mathrm{m}^{3}\right) \\
\text { as a proportion of the } \\
\text { volume in Table 3 }\end{array}$ & $\begin{array}{l}\text { Volume estimate of total } \\
\text { thickness post-1945 }\left(\mathrm{m}^{3}\right) \\
\text { as a proportion of the } \\
\text { volume in Table 3 }\end{array}$ & $\begin{array}{l}\text { Accretion } \\
\text { rate } \\
\text { post-1945 } \\
\left(\mathrm{mm} \mathrm{yr}^{-1}\right)\end{array}$ \\
\hline $\begin{array}{l}\text { City of London } \\
\text { Tower Hamlets }\end{array}$ & $\begin{array}{l}7,422,030 \\
30,681,168\end{array}$ & $\begin{array}{l}4,358,970 \\
24,106,632\end{array}$ & 19.2 \\
\hline
\end{tabular}

175 to $125 \mathrm{yr}$ ago, as the city expanded. These estimates are based upon an assumption that construction material was largely stone and that $5 \mathrm{~m}$ of stone (of average $2.35 \mathrm{~g} / \mathrm{cm}^{3}$ ) was imported per square metre. Such historical estimates of the mass of the built environment for London appear reasonable compared with our modern mass determinations for the City of London and Tower Hamlets. However, given that these two boroughs represent just $1.44 \%$ of the total area of the $1595 \mathrm{~km}^{2}$ of Greater London, if a comparable average thickness of AMG was to be extrapolated across the Greater London area, the AMG present would weigh 11,250 Mt.
As mentioned previously (Section 5.2), proximity to the River Thames plays a significant role in increasing the average AMG thickness in the study area; as this will not be applicable to the majority of the Greater London area the extrapolated calculations are likely to be an overestimate. To determine a more accurate value, the percentage of the total Greater London area $\left(1595 \mathrm{~km}^{2}\right)$ that both contains and is outside of a $500 \mathrm{~m}$ buffer of the Thames was calculated and then multiplied against the mean thicknesses of AMG of within (3.72 m) and outside $(2.42 \mathrm{~m}$ ) of the $500 \mathrm{~m}$ buffer (see Table 4 ) to provide a revised volume of AMG (Table 9).

The revised estimates of AMG volumes were then further multiplied by $1.5 \mathrm{t}$ per $\mathrm{m}^{3}$ to obtain the overall mass as shown in Table 9. This presented an estimate of $5960 \mathrm{Mt}$ of AMG for the total combined area of the Greater London Authority, with roughly $8.1 \%$ of the subsurface mass occurring within $500 \mathrm{~m}$ of the River Thames, despite it only occupying $5.45 \%$ of the total Greater London area. The total proportion of AMG would further increase if the tributaries of the River Thames such as the River Lea and the River Fleet were taken into account.

Second, it has been estimated by Tanikawa and Hashimoto (2009) for Salford, United Kingdom, that the built environment equates to $1.118 \mathrm{Mt} / \mathrm{km}^{2}$. Application of a comparable mass in the current study areas would lead to estimates of $3.24 \mathrm{Mt}$ of built environment in the City of London and 22.10 Mt in Tower Hamlets. Given the volume of buildings found in both areas (Table 3 ), this would appear a significant underestimate; in the City of London it would equate with a density of $0.06 \mathrm{~g} / \mathrm{cm}^{3}$. There is a clear need to have estimates of the density of particular building types. The density of component building materials is known (see Tanikawa and Hashimoto, 2009), but without an understanding of how these materials are distributed in particular building styles of particular ages and what percentage of buildings comprises voids it is not possible to provide a more accurate determination of the mass of the built environment.

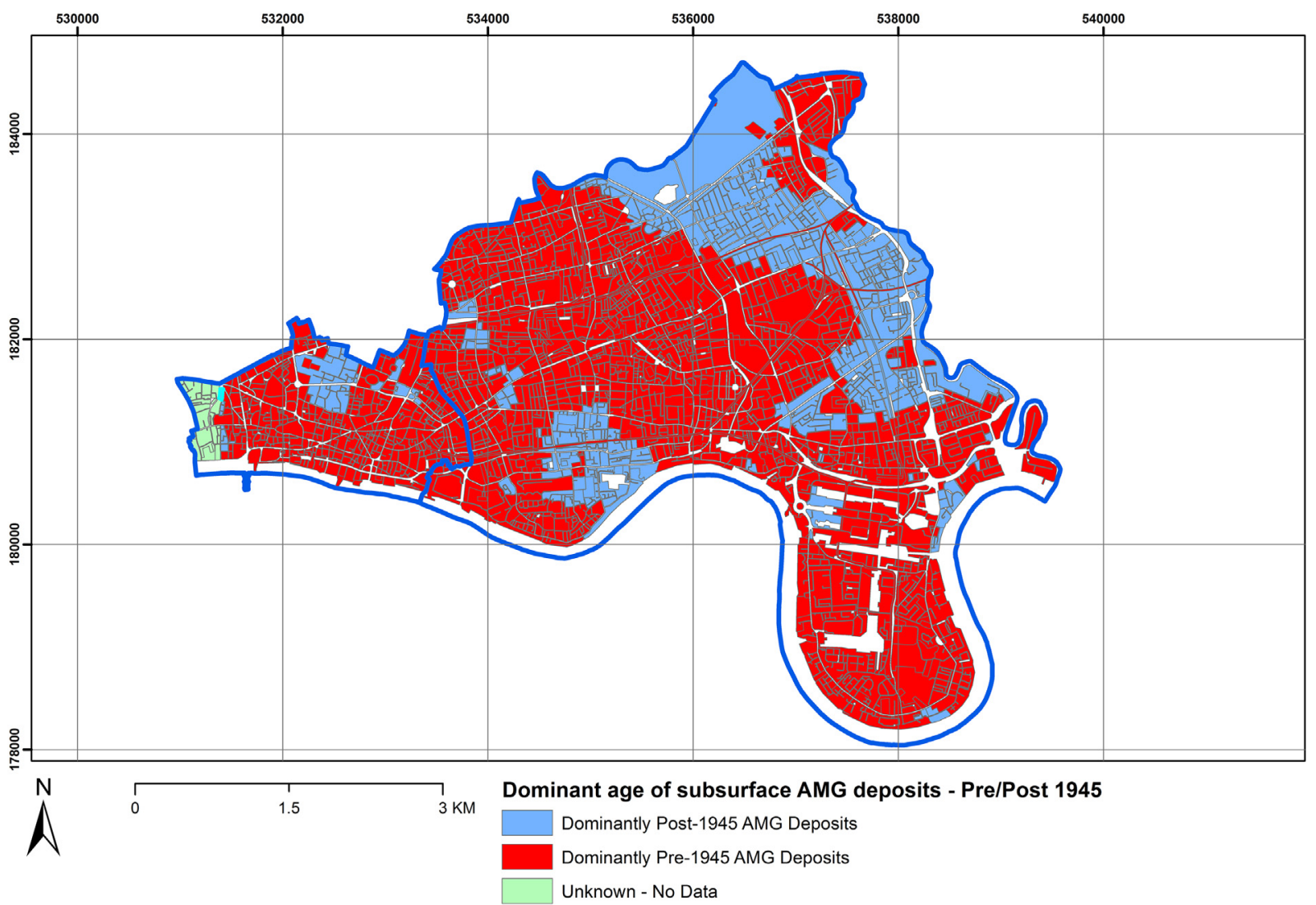

Fig. 12. Dominant age of subsurface deposits pre/post-1945. 

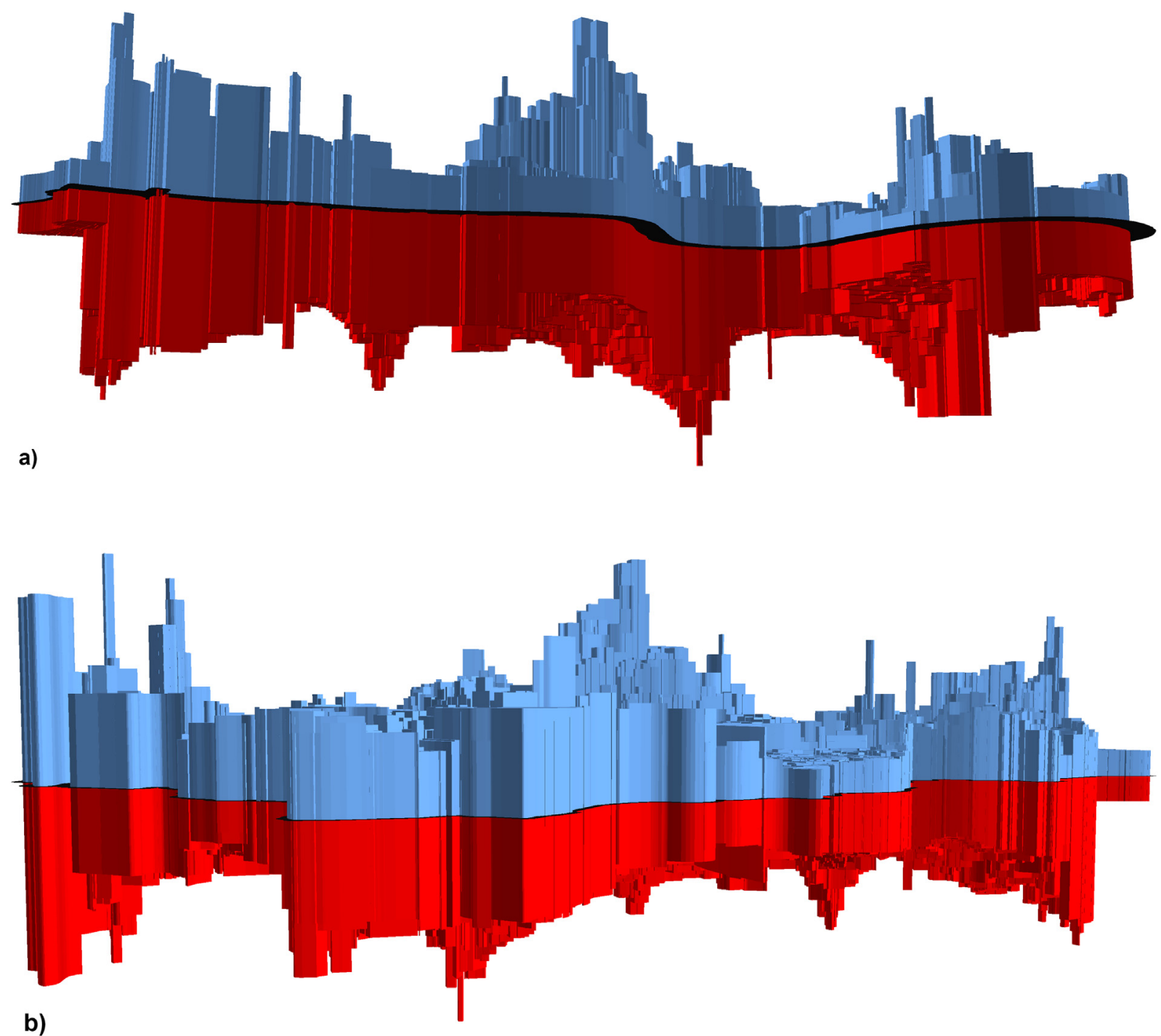

Fig. 13. (a) 3D proportion of pre-/post-1945 AMG deposits looking from a south to north direction and (b) looking from a north to south direction.

8.2. Relationship of anthropogenic mass burden and underlying natural geology to areas of recent subsidence

Rates of natural compaction and regional subsidence have not been taken into account in this study. Between 1997 and 2005, satellite-based persistent scatterer interferometry has recorded average regional subsidence in the London area of from $0.9-1.5 \mathrm{~mm} \mathrm{yr}^{-1}$ (Aldiss et al., 2014), consistent with a late Holocene subsidence rate of $0.9-1.0 \mathrm{~mm} \mathrm{yr}^{-1}$ estimated by Gehrels (2010) from geological observations. Given a realistic subsidence rate of $1.0 \mathrm{~mm} \mathrm{yr}^{-1}$, anthropogenic deposits that accumulated during Roman times in the City of London are now at elevations some $2 \mathrm{~m}$ lower than at the time of deposition; for those deposited at the end of WWII this tectonic subsidence would be only about $7 \mathrm{~cm}$, probably within the range of uncertainty in quoted elevations in borehole records.
Further analysis of ground motion data in London from 1992 to 2010 shows ground elevation change, which for the study area have been attributed to the processes of compaction of River Thames floodplain deposits (Cigna et al., 2015). Other anthropogenic processes, including groundwater abstraction, underground engineering works and the presence of Made Ground were also considered a significant influence (Cigna et al., 2015). The Canary Wharf area of Tower Hamlets was recognised as a broad area of subsidence in the range of 1$2.99 \mathrm{~mm} \mathrm{yr}^{-1}$ between 1992 and 2000 (Cigna et al., 2015), coinciding with the timing of the development of the around the former docks, starting in 1988. Nearby, the area around the northern end of the Blackwall Tunnel, Blackwall Basin and West India Dock (Fig. 9a) saw an elevation increase locally up to $3-8 \mathrm{~mm} \mathrm{yr}^{-1}$ over the same duration, believed to be linked to a phase of groundwater recharge recorded between 1996 and 2001 (Cigna et al., 2015). In both areas the subsidence

Table 9

Volume and mass of AMG for the near-shore area of the River Thames for Greater London.

\begin{tabular}{|c|c|c|c|c|}
\hline & Area $\left(\mathrm{km}^{2}\right)$ & Area \% & Volume of AMG $\left(\mathrm{m}^{3}\right)$ & Mass (tonnes) \\
\hline Within 500 m distance of the River Thames (Greater London) & 87 & 5.45 & $323,640,000$ & $485,460,000$ \\
\hline Outside 500 m distance of the River Thames (Greater London) & 1508 & 94.55 & $3,649,360,000$ & $5,474,040,000$ \\
\hline
\end{tabular}


and elevation rise had apparently ceased between 2002 and 2010 (Cigna et al., 2015). High subsidence rates of 0.99-21-mm yr ${ }^{-1}$ were seen in the Lea Valley at the eastern margin of Tower Hamlets from 2002 to 2010 (Cigna et al., 2015). The zone of subsidence at Canary Wharf broadly coincides with a 3 to $5 \mathrm{~m}$ average thickness of AMG (Fig. 8a and b), which may have undergone significant compaction following building of the high-rise developments, though the subsidence here is attributed by Cigna et al. (2015) to lowering of the groundwater level during building construction. The Lea Valley subsidence is in an area of 2 to $3 \mathrm{~m}$ of AMG (Fig. 8a). Both areas of higher subsidence rates coincide with areas underlain by River Thames alluvium and may reflect compaction of the natural deposits as well as artificial deposits due to the additional overburden resulting from development. Additionally, cut and fill processes from the Olympic Park may have contributed to the increased AMG being deposited in these areas which may have been a contributing factor to the subsidence in this area.

\subsection{Rate of AMG accumulation}

An apparent accretion rate of $19.2 \mathrm{~mm} \mathrm{yr}^{-1}$ for City of London and $15.5 \mathrm{~mm} \mathrm{yr}^{-1}$ for Tower Hamlets can be determined for the Anthropocene by relating the mean post-1945 deposit thickness (Table 8) to an accumulation duration of $72 \mathrm{yr}$. These are unprecedentedly high values. Sediment accumulation rates in the deep oceans are typically on the scale of 1-4 $\mathrm{m} \mathrm{Myr}^{-1}$ (Tyson and Pearson, 1991), which leaves the Anthropocene of sub-millimetric thickness. In contrast, average alluvium accumulation rates of $\sim 12,600 \mathrm{~m} \mathrm{Myr}^{-1}$ (or $12.6 \mathrm{~mm} \mathrm{yr}^{-1}$ ) are estimated post-settlement (Wilkinson and McElroy, 2007). For short durations at least, the accumulation of AMG exceeds such alluvial accumulation rates. Equivalent accumulation rates for pre-1945 deposits are less easily constrained, as the age of onset of deposition is poorly constrained and successions are marked by prolonged hiatuses. For parts of City of London with $1900 \mathrm{yr}$ of occupation prior to $1945 \mathrm{CE}$, the comparable accretion rate of the average thickness of $3.2 \mathrm{~m}$ (Table 7) would be only $\sim 1.7 \mathrm{~mm} \mathrm{yr}^{-1}$.

The rich array of archaeological data found across London (Brigham, 2000; Fig. 4a-c) provides a valuable resource in showing the lateral growth of the city from Roman to Medieval times. Its significance would be greatly advanced if the elevation data for these finds were also available. This could be incorporated alongside the borehole derived elevation differentials when comparing against a modern DTM to enhance the detail in which humans have modified the landscape (Section 5.1). The value of the integration of archaeological data to modern DTMs is demonstrated by Bini et al. (2018), who were able to use such data to model the accretion rates of successive eras of development in Pisa, Italy.

\section{Conclusions}

The first $1500 \mathrm{yr}$ of the history of the development of central London is characterised by vertical accretion of artificial deposits constrained by the city walls to a limited area within the City of London. This accumulation infilled the natural Holocene palaeotopography, largely constrained by the underlying geology. During the Industrial Revolution, a rapid expansion in the city's population led to the first major phase of lateral accretion of artificial deposits coincident with urbanisation of Tower Hamlets. The city has experienced two catastrophic events that should be clearly represented within these deposits, the Great Fire of London in 1666 and the Blitz of 1940 to 1945. In addition to being prominent marker horizons associated with building destruction, they represent boundaries between distinct deposit compositions caused by the use of radically different building construction materials before and after both events. The Great Fire will only have expression within the City of London in this study area (and is not evidenced from borehole data analysed in this study), whereas the Blitz affects the entire area and beyond to larger parts of London, but with analogous signals in other urban centres in the UK and Europe. However, there is no strong correlation between the thickness and composition of debris associated with the Blitz and the extent of the main area of destruction. This supports the record that much of the bomb debris was exported to infill the Lea Valley on the outskirts of the study area. Importantly, it is the significant change in both building materials and the nature of the waste products from energy consumption that permits recognition of the prominent mid-twentieth boundary within these deposits, which broadly corresponds to the start of the Anthropocene Epoch in which similar transitions are recognised globally (Zalasiewicz et al., 2017b). Notably, the presence of concrete is the strongest marker for deposits of Anthropocene age (Table 2), with plastic comparatively rarely described in these deposits. The inferred low abundance of coal and ash in Anthropocene deposits was partly recognised in the City of London, but was not a rigorous association probably due to reworking of underlying pre-WWII deposits during post-1945 building developments. These indicators suggest that a significant proportion of the thickness of AMG in the City of London post-dates WWII, despite representing only about 3\% of the duration of development in the area. Post-1945 development is associated with some vertical accretion of deposits, but also much reworking of older strata.

The AMG within the two studied London boroughs is estimated to have a mass of $99.9 \mathrm{Mt}$, with a mean thickness in the City of London of $3.74 \mathrm{~m}$, probably representing a longer duration of development than Tower Hamlets (mean thickness $=2.54 \mathrm{~m}$ ). However, the greatest thicknesses of AMG infills the Holocene palaeotopography and hence occurs closest to the River Thames and tributary streams. Consequently, the higher mean values may reflect a greater proportion of the City of London occurring within proximity to the Thames. Interestingly, the relationship between the thickness of AMG and overlying building height is both positive (for new high-rise buildings) and negative (in areas of older building stock). The mapped distribution of thicker AMG, prone to post-depositional compaction and settlement, is located above potentially compressible natural Holocene alluvial deposits and permits recognition of areas of potential subsidence. This potential appears to be supported by recent analysis of ground motion data in London.

\section{Acknowledgments}

The authors publish with the approval of the Executive Director, British Geological Survey, Natural Environment Research Council. The work was funded by the Engineering Geology and Infrastructure Directorate, British Geological Survey.

We would like to thank São Paulo Research Foundation (FAPESP Process Number 2015/15449-9) who provided the funding for Érika Cristina Nesta-Silva to contribute to this study and Jon Ford of the British Geological Survey for his advice during the writing of this paper.

\section{References}

Abrams, E., 1994. How the Maya Built their World: Energetics and Ancient Architecture. University of Texas Press, Austin, TX

Aldiss, D, Burke, $H$., Chacksfield, B, Bingley, R Teferle, N., Williams, S, Blackman, D. Burren, R., Press, N., 2014. Geological interpretation of current subsidence and uplift in the London area, UK, as shown by high precision satellite-based surveying. Proc. Geol. Assoc. 125 (1):1-13. https://doi.org/10.1016/j.pgeola.2013.07.003.

Barton, N.J., 1962. The Lost Rivers of London: A Study of Their Effects Upon London and Londoners, and the Effects of London and Londoners Upon Them. 2962. Phoenix House LTD London; Leicester University, London.

Bini, M., Pappalardo, M., Rossi, V., Noti, V., Amorosi, A., Sarti, G., 2018. Deciphering the effects of human activity on urban areas through morphostratigraphic analysis: the case of Pisa, Northwest Italy. Geoarchaeology 33:43-51. https://doi.org/10.1002/ gea.21619.

Brigham, T., 2000. Introduction. In: Brigham, T. (Ed.), The Archaeology of Greater London: An Assessment of Archaeological Evidence for Human Presence in the Area Now Covered by Greater London. Museum of London Archaeology Service, London, pp. 1-8. 
British Geological Survey, 2006. North London, England and Wales Sheet 256. Bedrock and Superficial Deposits. 1:50 000 (Keyworth, Nottingham).

Burke, H., Mathers, S.J., Williamson, J.P., Thorpe, S., Ford, J., Terrington, R.L., 2014. The London Basin and superficial and bedrock Lithoframe 50 model. British Geological Survey Technical Report (OR/14/029). Nottingham, UK, p. 27.

Cigna, F., Jordan, H., Bateson, L., McCormack, H., Roberts, C., 2015. Natural and anthropogenic geohazards in Greater London observed from geological and ERS-1/2 and ENVISAT Persistent Scatterers ground motion data: results from the EC FP7-SPACE PanGeo Project. Pure Appl. Geophys. 172:2965-2995. https://doi.org/10.1007/ s00024-014-0927-3.

Cowie, R., Harding, C., 2000. Saxon settlement and economy from the Dark Ages to Domesday. In: Brigham, T. (Ed.), The Archaeology of Greater London: An Assessment of Archaeological Evidence for Human Presence in the Area Now Covered by Greater London. Museum of London Archaeology Service, London, pp. 171-206.

Department Of Planning And Transportation, 1994. Conservation areas in the City of London: a general Introduction to their character (60 pp).

Edgeworth, M., Richter, D., De, B., Waters, C.N., Haff, P., Neal, C., Price, S.J., 2015. Diachronous beginnings of the Anthropocene: the lower bounding surface of anthropogenic deposits. Anthropocene Rev. 2 (1):1-26. https://doi.org/10.1177/ 2053019614565394.

Ford, J.R., Price, S.J., Cooper, A.H., Waters, C.N., 2014. An assessment of lithostratigraphy for anthropogenic deposits. In: Waters, C.N., Zalasiewicz, J.A. Williams, M., Ellis, M.A., Snelling, A.M. (Eds.), A Stratigraphical Basis for the Anthropocene. Geological Society, London, Special Publication 395:pp. 55-89. https://doi.org/10.1144/ SP395.12.

Gehrels, W.R., 2010. Late Holocene land- and sea-level changes in the British Isles: implications for future sea-level predictions. Quat. Sci. Rev. 29:1648-1660. https://doi.org/ 10.1016/j.quascirev.2009.09.015.

Gibbard, P.L. 1995. Palaeogeographical evolution of the Lower Thames Valley. In: Bridgland, D.R., Allen, P., Haggart, B.A. (Eds.), The Quaternary of the Lower Reaches of the Thames: Field Guide. Quaternary Research Association, Durham, pp. 5-34.

Greenwood, C., Greenwood, J., 1827. Map of London. 'From an actual survey made in the years 1824, 1825 \& 1826', and the date 'Aug. 21 1827'. British Library (Crace Collection of Maps of London).

Hooke, R.L., 2000. On the history of humans as geomporphic agents. Geology 28:843-846. https://doi.org/10.1130/0091-7613(2000)28\%3C843:OTHOHA\%3E2.0.CO;2.

Jones, L.D., Terrington, R., 2011. Modelling volume change potential in the London Clay. Q. J. Eng. Geol. Hydrogeol. 44 (1):109-122. https://doi.org/10.1144/1470-9236/08-112.

Kluiving, S.J., Hamel, A., 2016. How can archaeology help us unravel the Anthropocene?: RCC perspectives: transformations in environment and society. In: Ertsen, M.W., Mauch, C., Russel, E. (Eds.), Molding the Planet: Human Niche Construction at Work. Rachel Carson Center for Environment and Society, pp. 55-62.

Kranendonk, P., Kluiving, S.J., Troelstra, S.R., 2015. Chrono- and archaeostratigraphy and development of the River Amstel: results of the North/South underground line excavations, Amsterdam, the Netherlands. Geol. Mijnb. 94 (4):333-352. https://doi.org/ 10.1017/njg.2014.38.

LiDAR DTM, 2006. UK Perspectives a Joint Venture between Bluesky and Infoterra Limited (C) Getmapping: License Number UKP 2006/01 (2 m resolution DSM. 5 m resolution DTM).

Merrifield, R., 1965. The Roman City of London. Ernest Benn Limited, London.

Perring, D., Brigham, T., 2000. Londinium and its hinterland: the Roman Period. In: Brigham, T. (Ed.), The Archaeology of Greater London: An Assessment of Archaeological Evidence for Human Presence in the Area Now Covered By Greater London. Museum of London Archaeology Service, London, pp. 119-170.

Plan of Sewers (1843) - British Library. http://www.bl.uk/onlinegallery/onlineex/crace/p/ 007zzz000000018u000070a0.html

Rivas, V., Cendrero, A., Hurtado, M., Cabral, M., Giménez, J., Forte, L., Del Río, L., Cantu, M., Becker, A., 2006. Geomorphic consequences of urban development and mining activities; an analysis of study areas in Spain and Argentina. Geomorphology 73: 185-206. https://doi.org/10.1016/j.geomorph.2005.08.006.

Rose, J., Lee, J.A., Kemp, R.A., Harding, P.A., 2000. Paleoclimate sedimentation and soil development during the Last Glacial Stage (Devensian), Heathrow Airport, London, UK. Quat. Sci. Rev. 19, 827-847.

Schofield, J., 2000. Post-Medieval London: The expanding Metropolis. In: Brigham, T. (Ed.), The Archaeology of Greater London: An Assessment of Archaeological Evidence for Human Presence in the Area Now Covered By Greater London. Museum of London Archaeology Service, London, pp. 255-281.
Silva, É.C.N., 2016. Understanding and visualization of Artificial Ground in the City of London, Greater London, England. Research Internship Abroad Report Related to Project FAPESP n. 2015/15449-9 (BEPE)

Sloane, B., Harding, C., Schofield, J., Hill, J., 2000. From the Norman Conquest to Reformation. In: Brigham, T. (Ed.), The Archaeology of Greater London: An Assessment of Archaeological Evidence for Human Presence in the Area Now Covered By Greater London. Museum of London Archaeology Service, London, pp. 207-254.

Smith, B.D., Zeder, M.A., 2013. The onset of the Anthropocene. Anthropocene 4:8-13. https://doi.org/10.1016/j.ancene.2013.05.001.

Tanikawa, H., Hashimoto, S., 2009. Urban stock over time: spatial material stock analysis using 4d-GIS. Build. Res. Inf. 37:483-502. https://doi.org/10.1080/ 09613210903169394.

Terrington, R.L., Thorpe, S., Burke, H.F., Smith, H., Price, S.J., 2015. Enhanced mapping of artificially modified ground in urban areas: using borehole, map and remotely sensed data. British Geological Survey Technical Report (OR/15/010). Nottingham, UK, p. 38.

Thorpe, S., 2015. Metadata report for the Knowsley 3D geological model. Nottingham, UK, British Geological Survey (OR/15/020). Nottingham: UK, p. 13.

Tyson, R.V., Pearson, T.H., 1991. Modern and ancient continental shelf anoxia: an overview. In: Tyson, R.V., Pearson, T.H. (Eds.), Modern and Ancient Continental Shelf Anoxia. Geological Society Special Publication 58, pp. 1-24.

URBAN ATLAS, 2010. Mapping Guide for a European Atlas. European Environment Agency http://www.eea.europa.eu/data-and-maps/data/urban-atlas.

Verhagen, J.G.M., Kluiving, S.J., Anker, E., Van Leeuwen, L., Prins, M.A., 2017 Geoarchaeological prospection for Roman waterworks near the late Holocene Rhine-Waal delta bifurcation, the Netherlands. Catena 149:460-473. https://doi.org/ 10.1016/j.catena.2016.03.027.

Ward, L., 2015. Bomb Damage Maps (1939-1945). Thames \& Hudson Ltd, Farnborough. Waters, C.N., Zalasiewicz, J., 2018. Concrete: the most abundant novel rock type of the Anthropocene. In: DellaSala, D.A., Goldstein, M.I. (Eds.), The Encyclopedia of the Anthropocene. 1. Elsevier, Oxford:pp. 75-85. https://doi.org/10.1016/B978-0-12809665-9.09775-5.

Waters, C.N., Zalasiewicz, J., Summerhayes, C., Barnosky, A.D., Poirier, C., Gałuszka, A Cearreta, A., Edgeworth, M., Ellis, E.C., Ellis, M., Jeandel, C., Leinfelder, R., Mcneill, J.R., Richter, D. Deb, Steffen, W., Syvitski, J., Vidas, D., Wagreich, M., Williams, M., Zhisheng, An, Grinevald, J., Odada, E., Oreskes, N., Wolfe, A.P., 2016. The Anthropocene is functionally and stratigraphically distinct from the Holocene. Science 351 (6269):137. https://doi.org/10.1126/science.aad2622.

Wilkinson, B.H., McElroy, B.J., 2007. The impact of humans on continental erosion and sedimentation. Geol. Soc. Am. Bull. 119 (1/2):140-156. https://doi.org/10.1130/ B25899.1.

Williams, M., Zalasiewicz, J., Waters, C.N., Landing, E., 2014. Is the fossil record of complex animal behaviour a stratigraphical analogue for the Anthropocene? In: Waters, C.N. Zalasiewicz, J.A., Williams, M., Ellis, M.A., Snelling, A.M. (Eds.), A Stratigraphical Basis for the Anthropocene. Geological Society, London, Special Publication 395: pp. 143-148. https://doi.org/10.1144/SP395.8

Zalasiewicz, J., Waters, C.N., Williams, M., 2014. Human bioturbation, and the subterranean landscape of the Anthropocene. Anthropocene 6:3-9. https://doi.org/10.1016 j.ancene.2014.07.002

Zalasiewicz, J., Waters, C.N., Ivar Do Sul, J., Corcoran, P.L., Barnosky, A.D., Cearreta, A. Edgeworth, M., Gałuszka, A., Jeandel, C., Leinfelder, R., Mcneill, J.R., Steffen, W., Summerhayes, C., Wagreich, M., Williams, M., Wolfe, A.P., Yonan, Y., 2016. The geological cycle of plastics and their use as a stratigraphic indicator of the Anthropocene. Anthropocene 13:4-17. https://doi.org/10.1016/j.ancene.2016.01.002.

Zalasiewicz, J., Williams, M., Waters, C.N., Barnosky, A.D., Palmesino, J., Rönnskog, A.-S. Edgeworth, M., Neal, C., Cearreta, A., Ellis, E.C., Grinevald, J., Haff, P., Ivar Do Sul, J.A., Jeandel, C., Leinfelder, R., Mcneill, J.R., Odada, E., Oreskes, N., Price, S.J., Revkin, A. Steffen, W., Summerhayes, C., Vidas, D., Wing, S., Wolfe, A.P., 2017a. Scale and diversity of the physical technosphere: a geological perspective. Anthropocene Rev. 4 (1): 9-22. https://doi.org/10.1177/2053019616677743.

Zalasiewicz, J., Waters, C.N., Summerhayes, C., Wolfe, A.P., Barnosky, A.D., Cearreta, A. Crutzen, P., Ellis, E.C., Fairchild, I.J., Gałuszka, A., Haff, P., Hajdas, I., Head, M.J., Ivar Do Sul, J., Jeandel, C., Leinfelder, R., Mcneill, J.R., Neal, C., Odada, E., Oreskes, N., Steffen, W., Syvitski, J.P.M., Wagreich, M., Williams, M., 2017b. The working group on the 'Anthropocene': summary of evidence and recommendations. Anthropocene 19:55-60. https://doi.org/10.1016/j.ancene.2017.09.001. 